\title{
Mechanisms of immune escape in central nervous system infection with neurotropic JC virus variant
}

Jelcic, Ivan ; Jelcic, Ilijas ; Kempf, Christian ; Largey, Fabienne ; Planas, Raquel ; Schippling, Sven ; Budka, Herbert ; Sospedra, Mireia ; Martin, Roland

Abstract: OBJECTIVE: Symptomatic infections of the central nervous system (CNS) with JC polyomavirus (JCV) usually occur as a result of immunocompromise and manifest as progressive multifocal leukoencephalopathy (PML) or granule cell neuronopathy $(\mathrm{GCN})$. After immune reconstitution, some of these cases may show longterm persistence of JCV and delayed clinical improvement despite inflammation. METHODS: We followed 4 patients with multiple sclerosis, who developed natalizumab-associated PML or GCN with regard to JC viral load and JCV-specific T-cell responses in the CNS. All of them experienced immune reconstitution inflammatory syndrome (IRIS), but in 2 cases JCV persisted $>21$ months after IRIS accompanied by delayed clinical improvement. RESULTS: Persistence of JCV was associated with a lack of JCV VP1-specific T-cell responses during immune reconstitution in 1 of the patients. Detailed analysis of the brain infiltrate in another patient with neuronal persistence of JCV revealed strong infiltration of CD8(+) T cells and clonal expansion of activated CD8(+) effector $\mathrm{T}$ cells with a CD4(dim) CD8(+) phenotype, both exhibiting exquisite specificity for conserved epitopes of JCV large $\mathrm{T}$ antigen. However, clearance of JCV was not efficient, because mutations in the major capsid protein VP1 caused reduced CD4(+) T-cell responses against the identified JCV variant and subsequently resulted in a decline of CD8(+) T-cell responses after IRIS. INTERPRETATION: Our findings suggest that efficient CD4(+) T-cell recognition of neurotropic JCV variants is crucial to support CD8(+) T cells in combating JCV infection of the CNS. Ann Neurol 2016.

DOI: https://doi.org/10.1002/ana.24574

Posted at the Zurich Open Repository and Archive, University of Zurich

ZORA URL: https://doi.org/10.5167/uzh-123189

Journal Article

Accepted Version

Originally published at:

Jelcic, Ivan; Jelcic, Ilijas; Kempf, Christian; Largey, Fabienne; Planas, Raquel; Schippling, Sven; Budka, Herbert; Sospedra, Mireia; Martin, Roland (2016). Mechanisms of immune escape in central nervous system infection with neurotropic JC virus variant. Annals of Neurology, 79(3):404-418.

DOI: https://doi.org/10.1002/ana.24574 


\section{Mechanisms of Immune Escape in Central Nervous System Infection with Neurotropic JC Virus Variant}

Running head: Immune surveillance of neurotropic JC virus

Ivan Jelcic, $\mathrm{PhD}^{1}$, Ilijas Jelcic, $\mathrm{MD}^{1}$, Christian Kempf, $\mathrm{MD}^{1}$, Fabienne Largey ${ }^{1}$, Raquel Planas, $\mathrm{PhD}^{1}$, Sven Schippling, $\mathrm{MD}^{1}$, Herbert Budka, $\mathrm{MD}^{2}$, Mireia Sospedra, $\mathrm{PhD}^{1}$ and Roland Martin, MD ${ }^{1 \S}$

1 Neuroimmunology and Multiple Sclerosis Research Section, Department of Neurology, University Hospital Zurich, 8091 Zurich, Switzerland

${ }^{2}$ Institute of Neuropathology, University Hospital Zurich, 8091 Zurich, Switzerland

$\S$ Corresponding author:

Roland Martin, MD

Neuroimmunology and Multiple Sclerosis Research Section, Department of Neurology, University Hospital Zurich, Frauenklinikstrasse 26, 8091 Zurich, Switzerland

Email: roland.martin@usz.ch; phone: +41 - 442551125

Character count in the title and running head: 84 (title) and 38 (running head)

Word count abstract: 242

Word count introduction: 493

Word count discussion: 1499

Word count overall: 5457

Number of figures: 6 


\section{ABSTRACT}

Objective: Symptomatic infections of the central nervous system (CNS) with JC polyoma virus (JCV) usually occur as a result of immunocompromise and manifest as progressive multifocal leukoencephalopathy (PML) or granule cell neuronopathy (GCN). After immune reconstitution, some of these cases may show long-term persistence of JCV and delayed clinical improvement despite inflammation.

Methods: We followed four patients with multiple sclerosis, who developed natalizumab-associated PML or GCN with regard to JC viral load and JCV-specific T cell responses in the CNS. All of them experienced immune reconstitution inflammatory syndrome (IRIS), but in two cases JCV persisted more than 21 months after IRIS accompanied by delayed clinical improvement.

Results: Persistence of JCV was associated with a lack of JCV VP1-specific T cell responses during immune reconstitution in one of the patients. Detailed analysis of the brain infiltrate in another patient with neuronal persistence of JCV revealed strong infiltration of $\mathrm{CD} 8^{+} \mathrm{T}$ cells and clonal expansion of activated $\mathrm{CD} 8^{+}$effector $\mathrm{T}$ cells with a CD4 ${ }^{\text {dim }}{ }^{2} D 8^{+}$phenotype, both exhibiting exquisite specificity for conserved epitopes of JCV large T antigen. However, clearance of JCV was not efficient, since mutations in the major capsid protein VP1 caused reduced $\mathrm{CD} 4^{+} \mathrm{T}$ cell responses against the identified JCV variant and subsequently resulted in a decline of $\mathrm{CD}^{+} \mathrm{T}$ cell responses after IRIS.

Interpretation: Our findings suggest that efficient $\mathrm{CD}^{+} \mathrm{T}$ cell recognition of neurotropic $\mathrm{JCV}$ variants is crucial to support $\mathrm{CD} 8^{+} \mathrm{T}$ cells in combating $\mathrm{JCV}$ infection of the CNS. 


\section{INTRODUCTION}

JCV can cause different neurological disorders in states of immunocompromise such as AIDS but emerged recently also in patients under monoclonal antibody therapies including multiple sclerosis (MS) patients treated with natalizumab, an anti-VLA-4 monoclonal antibody that prevents the migration of leukocytes through the bloodbrain-barrier. ${ }^{1-3}$ Infections of the CNS with JCV result in lytic destruction of oligodendrocytes or granule cell neurons leading to progressive multifocal leukoencephalopathy (PML) or granule cell neuronopathy $(\mathrm{GCN})$, respectively. ${ }^{3-5}$ Molecular characterization of PML- and GCN-associated JCV strains identified specific mutations particularly in the major capsid protein VP1, which may be associated with altered cellular tropism. ${ }^{6,7}$ Until now there is no treatment for PML or GCN, and the only way to eliminate JCV efficiently from the CNS is to restore immune competence, e.g. by eliminating the monoclonal antibody in patients under monoclonal antibody therapy. This in turn can lead to PML or GCN immune reconstitution inflammatory syndrome (PML-IRIS, GCN-IRIS) that is characterized by massive influx of JCV-specific T cells, B cells and monocytes into the CNS at the site of JCV infection. ${ }^{8}$ However, a subgroup of PML patients shows an unusually slow drop of JCV copy numbers in the CNS despite immune reconstitution and development of IRIS. ${ }^{9,10}$

Although it is not yet fully understood, which components of the immune system are involved in resolution of $\mathrm{JCV}$ infection in the brain, there is increasing evidence that $\mathrm{T}$ cells play a key role in eliminating the virus in the CNS. ${ }^{11}$ However, controversy exists concerning the roles of $\mathrm{CD} 4^{+}$or $\mathrm{CD}^{+} \mathrm{T}$ cells. Earlier studies emphasized the importance of $\mathrm{JCV}$-specific $\mathrm{CD} 8^{+} \mathrm{T}$ cell responses regarding better PML prognosis and survival. ${ }^{12,13}$ The co-localization of $\mathrm{CD} 8^{+} \mathrm{T}$ cells with JCV-infected glial cells corroborated the significance of $\mathrm{CD} 8^{+} \mathrm{T}$ cells in PML. ${ }^{14,}{ }^{15}$ However, the frequent 
occurrence of PML during HIV infection, its occurrence in idiopathic $\mathrm{CD}^{+}$ lymphopenia, the association of HLA class II alleles with JCV-specific T cell responses and the analysis of brain-infiltrating T cells in PML-IRIS all suggest that $\mathrm{CD}^{+} \mathrm{T}$ cells also play an important role in controlling JCV infection. ${ }^{16-21}$ Our analysis of brain-infiltrating lymphocytes in natalizumab-associated PML-IRIS demonstrated highly abundant and clonally expanded JCV VP1-specific CD4 ${ }^{+} \mathrm{T}$ cells, which deploy a broad spectrum of different strategies to mount an efficient JCV-specific immune response. $^{16,17}$

Here, we report that JC viral persistence in the CNS may occur even after immune reconstitution and despite intrathecal JCV-specific T cell and antibody responses. Detailed analysis of the brain-infiltrating $T$ cell subpopulations at onset of IRIS demonstrated differential antigen specificities with $\mathrm{CD} 8^{+} \mathrm{T}$ cells strongly responding to conserved JCV epitopes and $\mathrm{CD} 4^{+} \mathrm{T}$ cells mainly directed against VP1, where mutations are most frequently observed. Finally, we show that mutations of VP1 compromise the $\mathrm{CD} 4^{+} \mathrm{T}$ cell response and that $\mathrm{CD} 8^{+} \mathrm{T}$ cell responses decline in parallel. Our data suggest that efficient $\mathrm{CD} 4^{+} \mathrm{T}$ cell recognition of neurotropic $\mathrm{JCV}$ variants is required to support $\mathrm{JCV}$-specific $\mathrm{CD}^{+}$effector $\mathrm{T}$ cells in eliminating $\mathrm{JCV}$ from the brain. 


\section{MATERIALS AND METHODS}

\section{Ethics statement and patient information}

We collected blood and cerebrospinal fluid (CSF) from four patients with multiple sclerosis and concomitant natalizumab-associated or PML (patients 1-3) or GCN (patient 4) and additionally a brain biopsy from patient 4 for diagnostic reasons. Collection of human samples for research purposes was approved by the Cantonal Ethical Committee of Zürich, Switzerland (EC-ZH-No. 2013-0001). Samples were obtained with written informed consent of patients.

Patient 1 (male, 44 years old) was diagnosed with PML in June 2014 after incidental finding of asymptomatic left temporal lesions suspicious for PML and subsequent detection of JCV DNA in CSF. Four weeks after plasmapheresis, he complained of fatigue and verbal memory deficits corresponding to deterioration of EDSS from 1.5 to 2.0, and MRI showed contrast enhancement within the PML lesion, indicating PML-IRIS. After starting corticosteroid therapy, fatigue and verbal memory deficits improved permanently. In February 2015, no JCV DNA was detectable in CSF (Fig. 1), and MRI showed marked atrophy of the PML lesion with slight punctiform contrast enhancement, but no perilesional edema and no diffusion restriction, confirming successful remission from PML.

Patient 2 (male, 46 years old) developed progressive hypesthesia in both feet and hands in July 2012. MRI surprisingly showed new confluent T2-hyperintensive lesions in the right temporal and frontal region and smaller T2 lesions in the left uncal region and internal capsule. Subsequent CSF analysis proved PML by detection of JCV DNA. Four weeks after plasmapheresis he developed headache and progressive left sensorimotor hemisyndrome with typical MRI signs of PML-IRIS, leading to severe gait impairment and wheelchair-dependency. Corticosteroid treatment gradually improved the left hemiparesis enabling unrestricted ambulation 
by October 2012 and resulting in a residual state of mild left facio-brachial sensorimotor hemiparesis by February 2013. MRI showed marked atrophy of the PML lesions with few contrast-enhancing spots and no edema, and JCV DNA was undetectable in CSF in August 2013 (Fig. 1), confirming successful remission from PML.

In patient 3 (female, 45 years old), PML was diagnosed in May 2013 because of progressive right hemiparesis and dysarthria, detection of T2-hyperintense lesions in the left precentral gyrus, left thalamus and internal capsule and both cerebellar peduncles in MRI and detection of JCV DNA in CSF. Two weeks after plasmapheresis, right hemiparesis and dysarthria started to worsen (change from EDSS 4.0 to EDSS 9.0 within two weeks). Intense intralesional contrast enhancement was detected by MRI and PML-IRIS was diagnosed. After starting corticosteroid treatment EDSS improved to 7.5 until October 2013. MRI showed less contrast enhancement, but enlargement of left precentral and thalamic lesions, indicating PML progression. Corticosteroid treatment was stopped in February 2014. In June 2014, the right hemiparesis worsened because of further PML progression as indicated by diffusion restriction in the periphery of the left precentral lesion, but stabilized again until September 2014 with no further change in neurological deficits until March 2015 (EDSS 7.5). Repeated CSF analysis between July 2013 and March 2015 revealed persistence of JCV DNA 21 months after PML-IRIS. Therefore, the patient was designated "JCV non-clearer".

Patient 4 (female, 32 years old) was diagnosed with GCN in March 2012 because of progressive truncal and limb ataxia, MRI-proven cerebellar atrophy and detection of JCV DNA in CSF. ${ }^{22}$ By then, she needed unilateral assistance to walk at least $50 \mathrm{~m}$, corresponding to EDSS 6.0. Until June 2012, her cerebellar deficits worsened continuously without a correlate of new PML-/GCN or MS lesions in MRI. Because 
the clinical deterioration could not be attributed to GCN progression or IRIS, a diagnostic cerebellar biopsy was collected from the right cerebellar hemisphere, showing histopathological signs of GCN-IRIS. At this time, she was restricted to wheelchair and needed help in transferring to the bed, corresponding to EDSS 7.5. A single corticosteroid pulse therapy induced no changes, but gait ataxia improved slowly until May 2014, enabling her to walk maximally 40m without assistance (EDSS 6.5). 23 months after PML-IRIS, no new lesions were detectable in MRI, but CSF analysis showed $32 \mathrm{JCV}$ copies/ml (Fig. 1), consistent with "JCV non-clearer" status.

\section{CNS tissue and peripheral blood processing}

CSF-derived mononuclear cells were collected from diagnostic spinal taps, and PBMCs were separated by Ficoll density gradient centrifugation (PAA, Austria). A diagnostic brain biopsy of the GCN patient was taken from the right cerebellar hemisphere at onset of IRIS, from which a part was provided for research purposes. CNS tissue was processed immediately after surgery, as previously described. ${ }^{16}$

\section{Expansion of mononuclear cells and generation of T cell clones (TCC)}

Brain- and CSF-derived mononuclear cells were expanded as bulk populations with 1 $\mu \mathrm{g} / \mathrm{ml}$ phytohaemagglutinin (PHA, Sigma, USA) and human IL-2 (kindly provided by

Federica Sallusto, Bellinzona, Switzerland) as previously described. ${ }^{16}$ Expanded brain $\mathrm{CD}^{+}$were sorted on a FACSAria (BD) after staining for CD4 and CD8. TCC were generated by flow cytometry-based sorting of anti-TCR V $\beta 21.3 / 22$-labeled T cells and subsequent cloning by limiting dilution conditions using the above described expansion protocol. Antibodies used in the study are listed in Supplementary Table 1. 
JCV copy numbers in CSF were kindly determined by the Virology Institute of the University Zurich (samples with $>200$ copy numbers $/ \mathrm{ml}$ ) or at the Laboratory of Molecular Medicine and Neuroscience (NIH) (samples with <200 copy numbers/ml) using a quantitative PCR specific for JCV large T antigen (LTAg). The genome of the $\mathrm{JCV}_{\mathrm{GCN8}}$ variant (GenBank accession no. KM225765) from the cerebellar biopsy was identified by amplifying from extracted brain-derived DNA and sequencing multiple overlapping PCR fragments (400-700 bp) covering the whole JCV genome. Primers were obtained from Microsynth (Supplementary Table 2).

\section{Flow cytometric analysis}

For intracellular cytokine staining (ICS) of T cells, stimulation was performed either with $50 \mathrm{ng} / \mathrm{ml}$ phorbol myristate acetate (PMA) and $1 \mu \mathrm{g} / \mathrm{ml}$ lonomycin (Sigma) or specific peptide in the presence of Golgi-Plug (BD). After $5 \mathrm{~h}$ cells were stained with Live/Dead® Fixable Aqua Dead Cell Stain Kit (Invitrogen, USA), fixed and permeabilized with Cytofix/Cytoperm Kit (BD) and subsequently stained with fluorescently labeled antibodies. Measurements were performed on a LSR Fortessa Flow Cytometer (BD) and data was analyzed with FlowJo (Tree Star, USA). Heat maps were generated using Spice (NIH, NIAID, USA) software.

\section{JCV VP1 ELISA}

The level of JCV VP1/VLP-specific IgG antibodies was determined as described previously. ${ }^{20}$ Briefly, ELISA plates were coated with 200 ng of the JCV VLP per well and incubated with $\operatorname{CSF}(1: 2,1: 10,1: 100$ and 1:1000 dilutions). Human IgG was detected using biotin-conjugated anti-human IgG-Fc antibody and avidin horseradish peroxidase (eBioscience, Frankfurt, Germany). Optical density at $450 \mathrm{~nm}\left(\mathrm{OD}_{450}\right)$ was measured with a Synergy H1 microplate reader (BioTek, Lucerne, Switzerland). 
Antibody reactivity was assessed in arbitrary units (AU) using a standard curve obtained from a serial dilution of a standard serum for interpolating ODs by four parameter logistic curve fit.

\section{JCV epitope mapping}

166 JCV peptides (13-16-mer) with an overlap of five amino acids covering the JCV proteome were arranged in a set of 36 pools with each pool containing up to five peptides. All peptides were obtained from Peptides and Elephants (Germany, Supplementary Table 3). $2 \times 10^{4}$ PHA-expanded brain- or CSF-derived T cells were co-cultured with $1 \times 10^{5}$ irradiated autologous PBMC and peptide pools $(2 \mu \mathrm{M}$ per individual peptide) per well in X-Vivo. After 48 h, culture supernatants were analyzed for the release of IFN- $\gamma$ using ELISA (Biolegend, USA) and cells were further incubated with medium containing IL-2. Five days later, cells were restimulated with the identical peptide pools and $5 \times 10^{4}$ autologous EBV transformed B cells per well in the presence of Golgi-Plug (BD) followed by ICS as described above. Autologous EBV-transformed B cell lines were generated from PBMCs using the supernatant of the EBV-producing marmoset B cell line B95-8 and OKT3 antibody and were maintained in RPMI 1640 medium supplemented with 10\% FCS.

Antigen-specificity of individual TCCs was tested by using irradiated autologous PBMC and peptide pools or individual peptides at different concentrations. Additional blocking experiments of CD4 and CD8 co-receptors were performed by incubating prior to peptide stimulation with either a blocking antibody $(5 \mu \mathrm{g} / \mathrm{ml})$ for CD4 (clone RPA-T4) or CD8 (clone SIDI8BEE). After 48 h, culture supernatants were analyzed for the release of granzyme B, IFN- $\gamma$ and TNF using ELISA Kits (Biolegend, USA or Mabtech, Sweden). 


\section{Stimulation with freeze-thawed lysates}

A plasmid coding for JCV MAD1 VP1, VP2 and VP3 (kindly provided by Akira Nakanishi, Aichi, Japan) ${ }^{23}$ was used to substitute the VP1 $1_{\text {MAD1 }}$ sequence with the VP1 $1_{\text {GCN8 }}$ sequence identified in patient 4 . The plasmids were transfected into 293TT cells with Lipofectamine 2000 (Invitrogen). After $48 \mathrm{~h}$, cells were harvested, controlled for transfection efficiency and lysed with repetitive cycles of freeze-thaw treatment. Freeze-thawed lysates were then co-cultured with autologous irradiated PBMCs $\left(1 \times 10^{5}\right.$ cells/well) in X-Vivo for $4 \mathrm{~h}$ to allow appropriate uptake and antigen presentation. Thereupon, expanded brain-derived $\mathrm{CD}^{+} \mathrm{T}$ cells $\left(2 \times 10^{4}\right.$ cells/well) were added. After $48 \mathrm{~h}$, cell culture supernatants were taken to determine IFN- $\gamma$ release by ELISA (Biolegend). Furthermore, competition assays were performed by incubating autologous irradiated PBMCs for $4 \mathrm{~h}$ with freeze-thawed lysates containing $\mathrm{VP} 1_{\mathrm{MAD} 1}$ and then adding peptides pools (8 peptides with 1 amino acid overlap, $1 \mu \mathrm{M}$ per each individual peptide) covering the C-terminal region of either VP1 $1_{\text {MAD1 }}$ or VP1 $1_{G C N 8}$. After pre-incubation with peptides for $1 \mathrm{~h}$ sorted brain $\mathrm{CD} 4^{+} \mathrm{T}$ cells were added and secretion of IFN- $\gamma$ evaluated as described above.

\section{TCR analysis}

The TCR V $\beta$ repertoire of PHA-expanded cells was quantitatively determined by flow cytometry using anti-TCR V $\beta$ antibodies in combination with antibodies against CD4 and CD8 (Supplementary Table 1). Sequencing of TCR rearrangements and CDR3 length spectratyping was performed and analyzed as previously described. ${ }^{17}$

\section{Statistical analysis}


Statistical analyses were performed with paired Student's t test (Microsoft Excel). P values of $<0.05$ were considered as statistically significant. 


\section{RESULTS}

\section{Delayed elimination of neurotropic JCV despite immune reconstitution}

During clinical monitoring of four MS patients, who developed clinical manifestations of JCV infection in the CNS (patients 1-3 with PML and patient 4 with GCN) during natalizumab treatment, we observed an unusually slow elimination of JCV in the CSF in two patients (Fig. 1A). In contrast to patients 1 and 2, who cleared JCV rapidly and showed MRI-proven and clinical remission of PML, JCV non-clearers (patient 3 and 4) still disclosed detectable amounts of JCV after 21 (patient 3) or even 23 months (patient 4) and had a worse clinical outcome after one year despite the occurrence of IRIS. IRIS was diagnosed in all cases based on acute worsening of PML- or GCNrelated symptoms, and MRI contrast enhancement of PML-lesions or biopsy-proven immune infiltration of JCV-infected tissue. Increasing cell counts and anti-JCV VP1 antibody levels in the CSF also supported the presence of immune reconstitution in the CNS (Fig. 1B and 1C).

Since IRIS is characterized by strong infiltration of T cells, we further evaluated the responses of CNS-infiltrating T cells to the JCV major capsid protein VP1 at onset of IRIS. Whereas CNS-infiltrating T cells of JCV clearer (patient 1 and 2) revealed IFN- $\gamma$ responses to VP1, we observed a lack of VP1-specific responses and an overall low level of IFN- $\gamma$ secretion upon PHA stimulation in JCV non-clearer patient 3 (Fig. 1D) indicating an insufficient T cell response to JCV. Surprisingly, CNS-infiltrating, in particular brain-infiltrating T cells of JCV non-clearer patient 4 displayed strong IFN- $\gamma$ responses to VP1 (Fig. 1D). However, JC viral load dropped only slowly. Interestingly this patient was diagnosed with $\mathrm{GCN}^{22}$, a clinical manifestation of JCV infection, in which knowledge about immune surveillance and clearance mechanisms still remain scarce. 


\section{Absence of strong Th1-mediated $\mathrm{CD4}^{+} \mathrm{T}$ cell response to $\mathrm{JCV}$ antigens in a patient with persistent JCV infection}

Detailed characterization of the CSF-derived T cell infiltrate revealed the presence of $\mathrm{CD}^{+} \mathrm{T}$ cells, $\mathrm{CD} 8^{+} \mathrm{T}$ cells and a subpopulation of $\mathrm{CD} 4^{\mathrm{dim}} \mathrm{CD} 8^{+} \mathrm{T}$ cells which have been reported to represent activated $\mathrm{CD}^{+} \mathrm{T}$ cells $^{33}$ (Fig. 2A). CD4 ${ }^{+} \mathrm{T}$ cell numbers were increased in the JCV clearer patients 1 and 2 compared to the JCV non-clearer patients (Fig. 2A). In all patients, the $T$ cell subsets exhibited an overall predominant Th1/Tc1 cytokine profile in the CSF, although a part of the infiltrating $T$ cells expressed also a bifunctional Th1-2 phenotype (IFN- $\gamma^{+}$IL-4 $4^{+}$(Fig. 2B). Among the subsets, $C D 4^{\text {dim }} C D 8^{+} \mathrm{T}$ cells secreted the largest amount of the proinflammatory cytokines IFN- $\gamma$ and TNF in all 4 patients, which points at an important role of this subpopulation during viral clearance. However, in contrast to the other patients JCV non-clearer patient 3 showed a marked decrease of IFN- $\gamma^{+} \mathrm{CD}^{+} \mathrm{T}$ cells during followup explaining the insufficient IFN- $\gamma$ secretion in response to VP1 (Fig. 2B).

To determine the specificity of the CSF-infiltrating $T$ cells we performed epitope mapping using 36 peptide pools covering the whole proteome of the prototypic $\mathrm{JCV}_{\mathrm{MAD1}}$ strain. The CSF T cell infiltrates revealed strong $\mathrm{CD} 4^{+} \mathrm{T}$ cell responses to selective JCV antigens in patient 1, 2 and 4, whereas responses to JCV epitopes in JCV non-clearer patient 3 were only very weak or even absent indicating an inefficient immune control of $\mathrm{JCV}$ in this patient. Whereas CSF-infiltrating CD4 $4^{+} \mathrm{T}$ cells of patient 1 preferentially responded to LTAg epitopes and VP1 peptide pools 4 and 10, CD4 ${ }^{+} \mathrm{T}$ cells of patient 2 and 4 were primarily stimulated by VP1 epitopes. In contrast to the clear responses in $\mathrm{CD}^{+} \mathrm{T}$ cells, the responses of CSF-infiltrating $\mathrm{CD}^{+} \mathrm{T}$ cells were weak in all four patients. Furthermore, at the time of peak 
responses, $\mathrm{CD} 8^{+} \mathrm{T}$ cells and $\mathrm{CD} 4^{+} \mathrm{T}$ cells from each patient targeted different $\mathrm{JCV}$ epitopes.

\section{Brain-infiltrating T cell subsets are directed against different JCV proteins}

In order to understand the long-term persistence of JCV in patient 4 (GCN) despite experience of IRIS and strong T cell recognition of JCV VP1, we characterized in detail the functional phenotype and antigen specificity of the brain-infiltrating $T$ cell populations due to the availability of a diagnostic brain biopsy at onset of GCN-IRIS. The inflammation was characterized by a prominent $T$ cell infiltrate consisting of $\mathrm{CD} 8^{+} \mathrm{T}$ cells $(66 \%)$, to a lesser extent of $\mathrm{CD} 4^{+} \mathrm{T}$ cells $(24 \%)$ and $\mathrm{CD} 4^{\mathrm{dim}} \mathrm{CD} 8^{+} \mathrm{T}$ cells (5.2\%) (Fig. 3A and 3B).

We then further determined the fine specificity of the brain-infiltrating $T$ cells by performing $\mathrm{JCV}_{\text {MAD1 }}$ epitope mapping. Overall, brain-derived bulk $\mathrm{T}$ cells recognized most of the peptide pools and thereby several epitopes encoded by all six open reading frames of JCV (Fig. 3C). Nevertheless, responses were considerably stronger to peptide pools 3-10 covering almost the entire VP1 protein with exception of peptide pool 11, which consists of the C-terminal region of VP1. Re-stimulation of the brain-infiltrating T cells with the JCV peptide pools and subsequent ICS for IFN- $\gamma$ allowed us to separate the responses of $\mathrm{CD}^{+}, \mathrm{CD} 8^{+}$and $\mathrm{CD} 4^{\mathrm{dim}} \mathrm{CD} 8^{+} \mathrm{T}$ cells (Fig. 3D). Surprisingly, $\mathrm{CD} 4^{+}$and $\mathrm{CD} 8^{+} \mathrm{T}$ cell responses differed clearly in their JCV recognition pattern. Whereas the response of $\mathrm{IFN}-\gamma^{+} \mathrm{CD}^{+} \mathrm{T}$ cells was mainly directed against peptide pools in VP1 and small T antigen (sTAg), CD8 ${ }^{+} \mathrm{T}$ cells primarily responded to several epitopes derived from VP2/3 and large $T$ antigen (LTAg) (Fig. 3D). Interestingly, responses of $\mathrm{CD} 4^{\text {dim }} \mathrm{CD} 8^{+} \mathrm{T}$ cells (activated CD8 ${ }^{+} \mathrm{T}$ cells) were very strong amongst the $\mathrm{CD} 8^{+} \mathrm{T}$ cell responses. 


\section{Clonal expansion of activated $\mathrm{CD}^{+} \mathrm{T}$ cells that co-express $\mathrm{CD} 4$}

Compared to conventional $\mathrm{CD} 8^{+} \mathrm{T}$ cells, $\mathrm{CD} 4^{\mathrm{dim}} \mathrm{CD} 8^{+} \mathrm{T}$ cells are often found in increased numbers in chronic infections, display an activated phenotype and mediate strong antiviral immunity against multiple viruses. ${ }^{24-26}$ However, their function is as yet poorly understood and since this subpopulation has so far not been reported in JCV-associated CNS diseases, we examined their capacity for viral clearance. Immunostaining of freshly isolated mononuclear cells from the cerebellar tissue demonstrated the abundant presence of infiltrating $\mathrm{CD} 4^{\mathrm{dim}} \mathrm{CD}^{+} \mathrm{T}$ cells with an activated effector memory phenotype according to the expression of the activation markers HLA-DR and CD38 (Fig. 4A).

Further characterization of the TCR $V \beta$ repertoire revealed a massive expansion of a fraction of $C D 4^{\text {dim }} C D 8^{+} T$ cells in the brain since the expression of two TCR V $\beta$-chain families, $V \beta 22$ and $V \beta 21.3$, made up $83 \%$ of this subset and more than $4 \%$ of the whole $\mathrm{T}$ cell infiltrate (Fig. 4B). To identify individual TCCs within the above population, we sorted brain $C D 4^{\text {dim }} C D 8^{+} T$ cells for the two prominent $T C R$ V $\beta$-chains 21.3 and 22 , and by using TCR $\vee \beta$ CDR3 spectratyping and sequencing we confirmed clonal expansions of three distinct CDR3 sequences (Fig. 4C). Since it has been reported that $\mathrm{CD} 4^{\mathrm{dim}} \mathrm{CD} 8^{+} \mathrm{T}$ cells originate from $\mathrm{CD}^{+} \mathrm{T}$ cells, which can transiently express the CD4 receptor after stimulation ${ }^{27}$, we proved that $C D 4^{\text {dim }} C D 8^{+}$ TCCs arise from the single $\mathrm{CD} 8^{+}$but not $\mathrm{CD} 4^{+} \mathrm{T}$ cell compartment by using a PCR specific for the identified TCR V $\beta$-chains of $C D 4^{\text {dim }} C D 8^{+}$TCCs (Fig. 4D).

\section{Activated $\mathrm{CD}^{+} \mathrm{T}$ cells recognize antigen with high affinity and mount Tc1 responses to conserved LTAg epitopes}


Extraction of genomic DNA from the cerebellar biopsy of patient 4 (229 JCV DNA copies/cell) enabled us to identify a single novel JCV strain (GenBank no.: KM225765), which contained three deletion sites within LTAg and VP2/VP3 compared to the sequence of the prototypic $\mathrm{JCV}_{\text {MAD1 }}$ strain (Fig. 4E). Mapping of the target epitope of one of the three most prominent $C D 4^{\text {dim }}$ CD $8{ }^{+}$TCCs showed strong recognition of peptide pool 27, which consists of conserved epitopes in LTAg (Fig. $4 \mathrm{~F}$ ) and matched with the recognition pattern of bulk brain $\mathrm{CD} 4^{\mathrm{dim}} \mathrm{CD} 8^{+} \mathrm{T}$ cells responding overall to conserved epitopes in LTAg and VP2/VP3 (Fig. 3C). Only one

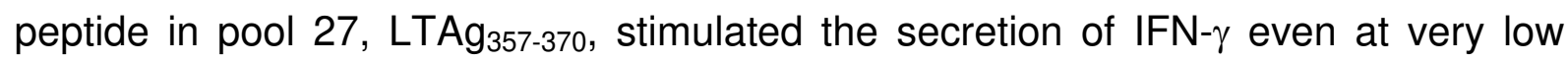
concentrations demonstrating high affinity recognition by the TCC (Fig. 4G). Stimulation with $\operatorname{LTAg}_{357-370}$ resulted in secretion of the proinflammatory Tc1 cytokines IFN- $\gamma$ and TNF as well as high levels of granzyme B suggesting strong cytotoxic potential (Fig. $4 \mathrm{H}$ ). All responses to $\mathrm{LTAg}_{357-370}$ were dependent on the CD8 co-receptor but not CD4 as shown by competition with specific blocking antibodies (Fig. 4H), supporting that the TCC functionally belongs to the $\mathrm{CD}^{+} \mathrm{T}$ cell compartment.

\section{Mutations of $\mathrm{JCV}_{\mathrm{GCN} 8} \mathrm{VP1}$ compromise the $\mathrm{CD}^{+} \mathrm{T}$ cell response leading to a decline of $\mathrm{CDB}^{+} \mathrm{T}$ cell responses}

As shown above, brain-infiltrating $\mathrm{CD}^{+} \mathrm{T}$ cells preferentially responded to VP1 epitopes. Therefore, we addressed the response of $\mathrm{CD}^{+} \mathrm{T}$ cells against the autologous neurotropic $\mathrm{JCV}_{\mathrm{GCN}}$ strain, which upon sequencing revealed multiple mutation sites in the coding region of VP1 compared to the prototypic $\mathrm{JCV}_{\mathrm{MAD} 1}$ strain (Fig. 5A). Noticeably, an in-frame deletion of six nucleotides led to the loss of a glutamine and a threonine in the C-terminal end of VP1, which is consistent with the characteristic mutation pattern found in VP1 of other $\mathrm{JCV}_{\mathrm{GCN}}$ strains. ${ }^{28,29}$ 
We developed a stimulation assay using lysates of 293TT cells transfected with plasmids coding for $\mathrm{VP} 1_{\mathrm{MAD} 1}$ or $\mathrm{VP} 1_{\mathrm{GCN} 8}$ that allowed us to study the brain $\mathrm{CD} 4^{+} \mathrm{T}$ cell responses to distinct JCV VP1 variants (Fig. 5B and 5C). Lysates of cells transfected with $\mathrm{VP} 1_{\mathrm{MAD} 1}$ and $\mathrm{VP} 1_{\mathrm{GCN}}$ stimulated IFN- $\gamma$ secretion of purified brain bulk $\mathrm{CD}^{+} \mathrm{T}$ cells (Fig. 5D). However, IFN- $\gamma$ secretion was significantly lower in response to $\mathrm{VP}_{\mathrm{GCN} 8}$, suggesting that $\mathrm{JCV}_{\mathrm{GCN}}$ mutations most likely affect recognition of critical epitopes by brain-infiltrating $T$ cells or result in a partial agonist or antagonist TCR ligands. Titration of both lysates showed clear dose-dependent responses (Fig. 5E).

Based on these observations we further tested the $\mathrm{CD} 4^{+} \mathrm{T}$ cell recognition of individual $\mathrm{JCV}_{\mathrm{GCN} 8}$ epitopes, in which mutations were found. Among these epitopes only one peptide, namely VP1 $1_{123-137}$, induced an IFN- $\gamma$ response in brain $\mathrm{CD} 4^{+} \mathrm{T}$ cells (data not shown). Interestingly, the variant peptide $\mathrm{VP}_{123-137} \mathrm{~T} 128 \mathrm{~A}$, in which a threonine at position 128 was substituted with alanine according to the mutation found in $\mathrm{JCV}_{\mathrm{GCN} 8}$, showed significantly less IFN- $\gamma$ secretion than the peptide with the prototypic MAD1 sequence (Fig. 5F). These differences remained at decreasing peptide concentrations, however, they do not sufficiently explain the poor recognition of $\mathrm{JCV}_{\mathrm{GCN} 8}$. Since peptides spanning all three other mutated areas in VP1 did not induce any response alone, we examined a possible antagonistic effect on $\mathrm{CD} 4^{+} \mathrm{T}$ cell responses using VP1 $1_{\text {MAD1 }}$ lysates in the presence of competitor peptides covering the area of $\mathrm{VP}_{67-82}, \mathrm{VP}_{151-165}$ and $\mathrm{VP} 1_{331-352}$ of either $\mathrm{JCV}_{\mathrm{MAD1}}$ or $\mathrm{JCV}_{\mathrm{GCN} 8}$. Only peptides spanning the C-terminal end of $\mathrm{VP} 1_{\mathrm{GCN} 8}$ 331-352, led to a reduction of IFN- $\gamma$ secretion by $C D 4^{+} \mathrm{T}$ cells in response to $\mathrm{VP} 1_{\mathrm{MAD} 1}$ lysate stimulation compared to a

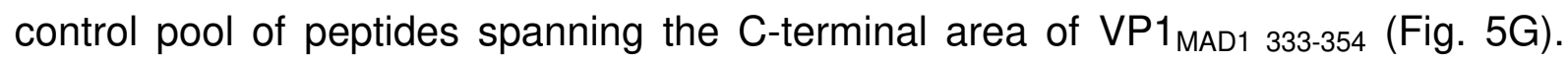


These results suggest that peptides within the C-terminus of JCV VP1 $1_{\mathrm{GCN} 8}$ mediate additional inhibitory effects.

Since $\mathrm{CD} 4^{+} \mathrm{T}$ cells are known to orchestrate efficient $\mathrm{CD} 8^{+} \mathrm{T}$ responses, we finally analyzed, if $\mathrm{CD}^{+} \mathrm{T}$ cell responses to LTAg changed with onset of IRIS and after IRIS. Interestingly, CSF-infiltrating T cell responses to a peptide pool covering the entire LTAg dropped significantly after IRIS despite the capacity to secrete comparable levels of IFN- $\gamma$ after PHA stimulation (Fig. $5 \mathrm{H}$ ). The drop in responses to LTAg was accompanied by a decline of $\mathrm{CD}^{+}$and $\mathrm{CD} 4^{\text {dim }} \mathrm{CD}^{+} \mathrm{T}$ cell numbers five months after IRIS (Fig. 5I). This observation most likely accounts for the inefficient viral clearance in this patient (Fig. 6). 


\section{DISCUSSION}

At present it is not known, which factors are most important to clear JCV from CNS in PML and GCN efficiently. The prominent T cell infiltrate during PML-IRIS and GCNIRIS points to a crucial role of brain-infiltrating $T$ cells in eliminating JCV from the brain. ${ }^{16,22,30}$ Importantly, the presence of both $\mathrm{CD}^{+}$and $\mathrm{CD}^{+} \mathrm{T}$ cells were described in brain biopsies of PML-IRIS and GCN-IRIS cases, indicating that both subpopulations are relevant for controlling JCV infection in the CNS. ${ }^{16,22,30}$ However, several studies reported dominant $\mathrm{CD} 8^{+} \mathrm{T}$ cell infiltrates in the brain during PML-IRIS ${ }^{14,30}$, but either lacked evidence for the presence of $\mathrm{CD} 4^{+} \mathrm{T}$ cells or were performed in AIDS patients. Recent data on intracerebral immune responses in PML-IRIS disclosed massive upregulation of HLA-class II in the brain, clonal expansion of CD4 ${ }^{+}$ $\mathrm{T}$ cells and a variety of strategies used by $\mathrm{CD} 4^{+} \mathrm{T}$ cells to efficiently clear JCV from infected glial cells. ${ }^{16,17}$ However, the knowledge about the function and specificity of brain-infiltrating T cells during JCV infection is still limited.

Interestingly, recent studies reported JC viral persistence in a subgroup of PML patients despite immune reconstitution ${ }^{9,}{ }^{10}$ questioning the role of $\mathrm{T}$ cells in this subcohort. Here we describe in two out of four natalizumab-associated PML/GCN patients JC viral persistence over 21 month despite development of IRIS. Evaluation of the immune reconstitution in a JCV non-clearer PML patient revealed absence of reactivity to VP1 as well as a generally very weak $\mathrm{CD} 4^{+} \mathrm{T}$ cell response to other $\mathrm{JCV}$ antigens and an overall low secretion of IFN- $\gamma$ in the CSF-infiltrating $\mathrm{CD}^{+} \mathrm{T}$ cell compartment, indicating why the immune response to JCV in the CNS may have been inefficient. Surprisingly, another JCV non-clearer, who suffered from GCN, remained JCV DNA-positive in the CSF after 2 years despite occurrence of pathologically prominent IRIS, strong recognition of $\mathrm{VP} 1_{\mathrm{MAD} 1}$ by brain-infiltrating $\mathrm{T}$ cells and increased intrathecal synthesis of VP1-specific antibodies. 
The availability of brain tissue of the GCN patient enabled us to examine in detail viral and immunological aspects of the brain infiltrate to explore potential reasons for incomplete elimination and persistence of JCV in the CNS. The novel JCV $\mathrm{JCN}_{\text {8 }}$ variant of this patient showed GCN-type mutations in the C-terminal region of VP1, consistent with recently reported $\mathrm{JCV}_{\mathrm{GCN}}$ variants in a second case of natalizumabassociated GCN and previously reported $\mathrm{JCV}_{\mathrm{GCN}}$ strains. ${ }^{28,29,31}$ Epitope mapping of brain-infiltrating $T$ cells revealed differential antigen specificity among the subpopulations and strong responses to $\mathrm{VP} 1_{\mathrm{MAD} 1}$ epitopes. Whereas $\mathrm{CD} 4^{+} \mathrm{T}$ cell responses were specifically directed against VP1 $1_{\text {MAD1 }}$ and sTAg MAD1 $_{1}, C D 8^{+} T$ cells primarily responded to several epitopes derived from VP2/3MAD1 and LTAgMAD1. The difference in epitope recognition between $\mathrm{CD} 4^{+}$and $\mathrm{CD} 8^{+} \mathrm{T}$ cell subsets may have several explanations including the fact that both subsets are restricted by different classes of HLA molecules and the expression of these on different target/antigen presenting cells with distinct antigen-processing pathways. By choosing an overlap of 5 amino acids between the peptides, we may have missed potential epitopes. However, a recent study on JCV epitope mapping using the same JCV peptide pools revealed that a wide range of different epitopes is recognized, that responses to all JCV peptide pools were detected and that there was high variability of reactivity against single JCV peptide pools between different individuals suggesting that the 15-mer peptides used in this work should be sufficient to uncover variability in epitope specificity. ${ }^{20}$

The preferential expression of LTAg in granule cell neurons ${ }^{32}$ suggests that $C D 8^{+} \mathrm{T}$ cells are the main effector cells for eliminating $\mathrm{JCV}_{\mathrm{GCN}}$-infected granule cell neurons. Interestingly, a large portion of the $\mathrm{JCV}$-specific $\mathrm{CD} 8^{+} \mathrm{T}$ cell responses was driven by an activated, highly abundant and clonally expanded $\mathrm{CD}^{+}$effector $\mathrm{T}$ cell subpopulation, which co-expresses CD4. The identification of the most relevant TCR 
sequences of $\mathrm{CD} 4^{\text {dim }} \mathrm{CD} 8^{+} \mathrm{T}$ cells in the $\mathrm{CD} 8^{+} \mathrm{T}$ cell compartment of the cerebellum demonstrated that this subset originates from $\mathrm{CD} 8^{+}$progenitors and upregulates $\mathrm{CD} 4$ inside the CNS. The upregulation of CD4 on $\mathrm{CD} 8^{+} \mathrm{T}$ cells can be induced by strong activation and has been shown to be involved in interacting with HLA-class II, IL-16induced chemotaxis and enhanced effector functions. ${ }^{25,}{ }^{33}$ Functional studies with one of the prominent brain-derived $\mathrm{CD} 4^{\text {dim }} \mathrm{CD}^{+}$TCCs revealed CD8-dependent recognition of a LTAg epitope with high affinity, Tc1 profile and cytotoxic potential. Since blocking of the $\mathrm{CD} 4$ receptor in the $\mathrm{CD} 4{ }^{\mathrm{dim}} \mathrm{CD} 8^{+} \mathrm{TCC}$ did not alter the response to the peptide, and since CD4 is known to serve as a receptor for soluble IL-16 ${ }^{33}$, we expect that co-expression of CD4 is primarily serving a role in chemotactic recruitment of $\mathrm{CD} 4^{\text {dim }} \mathrm{CD}^{+} \mathrm{T}$ cells to the site of inflammation in the cerebellum. Interestingly, granule cell neurons were reported to secrete soluble IL-16 upon caspase-3 cleavage of neuronal IL-16 (NIL-16), a variant of the IL-16 precursor. ${ }^{34} \mathrm{We}$ assume that the presence of cerebellar granule cell neuron-derived IL-16 favors the migration and/or maintenance of $\mathrm{CD} 4{ }^{\mathrm{dim}} \mathrm{CD}^{+} \mathrm{T}$ cells into the brain. Although there is growing evidence for an important role of $\mathrm{CD} 4^{\text {dim }} \mathrm{CD} 8^{+} \mathrm{T}$ cells in antiviral defense, their functional importance remains unclear. ${ }^{24,26} \mathrm{Here}$, we corroborate their important role as effector cells in targeting JCV-infected granule cell neurons by detecting marked expansion of mainly three TCCs in the brain, exquisite specificity to conserved JCV epitopes and Tc1 phenotype. The mechanisms of clearing JCVinfected neurons likely involves antigen-specific cytotoxicity via release of lytic granules containing granzyme $\mathrm{B}$ as we demonstrated for the $\mathrm{CD} 4^{\mathrm{dim}} \mathrm{CD} 8^{+} \mathrm{TCC}$ upon stimulation with the target LTAg antigen, but could also involve other antigenindependent mechanisms. ${ }^{35}$

Noteworthy, JCV viral load dropped relatively slowly in the CSF of the GCN patient despite the presence of LTAg-specific $\mathrm{CD}^{+}$effector T cells. Since $\mathrm{JCV}_{\mathrm{GCN}}$ variants 
infect neurons that lack MHC class II expression ${ }^{35}$, they may evade direct recognition by $\mathrm{CD}^{+} \mathrm{T}$ cells. Nevertheless, $\mathrm{CD}^{+} \mathrm{T}$ cells were present in the cerebellar infiltrate and still are expected to play an important role in orchestrating an efficient $T$ and $B$ cell response by recognizing JCV epitopes of phagocytosed JCV virions on antigen-presenting cells (APC). However, the presence of multiple mutations in VP1 of $\mathrm{JCV}_{\mathrm{GCN} 8}$ might impede efficient immune responses, since viral variations can affect neutralization by antibodies or generate naturally occurring viral peptide variants, known as altered peptide ligands, that prevent activation of $\mathrm{T}$ cells. ${ }^{36}$ To date, mutations in VP1 were only considered to affect the host receptor binding of JCV. ${ }^{7}$

Comparative antigen presentation of $\mathrm{VP} 1_{\mathrm{MAD} 1}$ and $\mathrm{VP} 1_{\mathrm{GCN}}$ peptides using lysates resulted in reduced IFN- $\gamma$ responses of brain $\mathrm{CD} 4^{+} \mathrm{T}$ cells to $\mathrm{VP} 1_{\mathrm{GCN} 8}$, indicating compromised recognition of mutated VP1 epitopes. Indeed, a variant VP1 epitope containing T128A of $\mathrm{JCV}_{\mathrm{GCN} 8}$ failed to induce full IFN- $\gamma$ secretion compared to the corresponding epitope of $\mathrm{VP} 1_{\mathrm{MAD} 1}$ indicating less efficient recognition of $\mathrm{VP} 1_{\mathrm{GCN}}$ by cerebellum-derived $\mathrm{CD} 4^{+} \mathrm{T}$ cells. Since $\mathrm{CD} 4^{+} \mathrm{T}$ cells did not respond to any of the other mutated VP1 epitopes, we investigated a possible antagonistic or competitive effect by these peptides, and indeed, the addition of peptides covering the C-terminal mutations of $\mathrm{JCV}_{\mathrm{GCN} 8}$ led to reduced $\mathrm{CD}^{+} \mathrm{T}$ cell responses. Based on the higher predicted binding affinities of C-terminal VP1 $1_{\mathrm{GCN} 8}$ peptides (data not shown), we assume that the less efficient response to the $\mathrm{JCV}_{\mathrm{GCN} 8} \mathrm{VP1}$ epitopes is at least in part due to competition for HLA-DR binding. Both mechanisms, i.e. reduced recognition of $\mathrm{JCV}_{\mathrm{GCN} 8} \mathrm{~T} 128 \mathrm{~A}$ and competition mediated by C-terminal epitopes of $\mathrm{VP} 1_{\mathrm{GCN} 8}$, might contribute to the slow elimination of $\mathrm{JCV}_{\mathrm{GCN} 8}$. The mutation-driven $\mathrm{CD}^{+} \mathrm{T}$ cell escape by the $\mathrm{JCV}_{\mathrm{GCN} 8}$ resulted not only in inefficient effector functions like IFN- $\gamma$ secretion but probably also in impaired support for $\mathrm{CD}^{+} \mathrm{T}$ cells, since 
$\mathrm{CD}^{+}$and $\mathrm{CD} 4^{\mathrm{dim}} \mathrm{CD}^{+} \mathrm{T}$ cells as well as reactivity to LTAg declined dramatically after IRIS. A potential causal relationship between JCV-specific $\mathrm{CD}^{+}$and $\mathrm{CD} 8^{+} \mathrm{T}$ cells in the brain is likely based on the supportive functions of $\mathrm{CD}^{+} \mathrm{T}$ cells via secretion of critical cytokines that maintain the survival, expansion and response of $\mathrm{CD}^{+} \mathrm{T}$ cells, as shown previously in the context of other viral infections. ${ }^{37,38}$

Our data provide novel information on host-pathogen interactions during CNS infection with JCV and illustrate alongside with the recently described antibody "recognition holes" for JCV variants in natalizumab-associated PML ${ }^{39}$ now for the first time also JC viral evasion mechanisms of $\mathrm{T}$ cell immunity driven by specific mutations in the viral genome during persistent JCV infection. Based on these observations we hypothesize that efficient $\mathrm{CD} 4^{+} \mathrm{T}$ cell recognition of neurotropic $\mathrm{JCV}$ variants is crucial to support $\mathrm{CD} 8^{+} \mathrm{T}$ cells for eliminating $\mathrm{JCV}$ infection of the CNS and prevent JC viral persistence (summarized in Fig. 6). Clinicians should be aware of relevant JCV mutations beyond the non-coding region. We recommend whole $\mathrm{JC}$ viral genome sequencing in cases of JCV persistence in CSF after PML-IRIS and concomitant studies on JC viral CNS immunity. Further research in this area should teach us more about the involvement of $\mathrm{JCV}$ variants in immune escape mechanisms in the brain and in general regarding immunity against viral infections in the CNS. Finally, this knowledge should help us to develop strategies to overcome JC viral immune evasion in these patients. 


\section{ACKNOWLEDGEMENTS}

We thank O. Bozinov, Department of Neurosurgery, University Hospital Zurich, Switzerland, for providing biopsy tissue, V. Demina and H. Manninga, Life Science Inkubator, Bonn, Germany, for providing JCV VP1 protein, A. Nakanishi, National Center for Geriatrics and Gerontology, Aichi, Japan, for supplying the plasmid pCAGJCV, F. Sallusto, Institute for Research in Biomedicine, Bellinzona, Switzerland, for providing IL-2, B. Piccapietra, Institute of Neuropathology, Zurich, Switzerland, for technical help and S. Hoffmeister-Ullerich, Centre for Molecular Neurobiology, Hamburg, Germany, for CDR3 spectratyping. The Neuroimmunology and Multiple Sclerosis Research Section is supported by the Clinical Research Priority Program on Multiple Sclerosis (CRPP ${ }^{\mathrm{MS}}$ ) of the University of Zurich, Switzerland. Ivan Jelcic was supported by the Swiss Multiple Sclerosis Society.

\section{AUTHOR CONTRIBUTIONS}

Iv. J., IL. J., M. S. and R. M. designed the study, interpreted data, and drafted the manuscript. IV. J., IL. J., C. K. and F. L. performed experiments, analyzed and interpreted data. R. P., Sv. S. and H. B. participated in the analysis and interpretation of the data. C. K., F. L., R. P., Sv. S. and H. B. revisited the article critically for important intellectual content. All authors approved the final version of the manuscript.

\section{CONFLICT OF INTEREST}

R. M., IL. J., Sv. S. and M. S. are listed as co-inventors on a patent on vaccination against PML by immunization with JCV VP1 protein licensed to Neuway Pharma, and R. M. and IV. J. on a patent of human monoclonal antibodies against JCV VP1 for 
passive vaccination/treatment of PML together with Neurimmune (Schlieren, Switzerland), which is pending. 


\section{REFERENCES}

1. Major EO. Progressive multifocal leukoencephalopathy in patients on immunomodulatory therapies. Annual review of medicine. 2010;61:35-47.

2. Kleinschmidt-DeMasters BK, Tyler KL. Progressive multifocal leukoencephalopathy complicating treatment with natalizumab and interferon beta-1a for multiple sclerosis. The New England journal of medicine. 2005 Jul 28;353(4):36974.

3. Gheuens S, Wuthrich C, Koralnik IJ. Progressive multifocal leukoencephalopathy: why gray and white matter. Annual review of pathology. 2013 Jan 24;8:189-215.

4. Koralnik IJ, Wuthrich C, Dang X, et al. JC virus granule cell neuronopathy: A novel clinical syndrome distinct from progressive multifocal leukoencephalopathy. Annals of neurology. 2005 Apr;57(4):576-80.

5. Du Pasquier RA, Corey S, Margolin DH, et al. Productive infection of cerebellar granule cell neurons by JC virus in an HIV+ individual. Neurology. 2003 Sep 23;61(6):775-82.

6. Dang X, Vidal JE, Oliveira AC, et al. JC virus granule cell neuronopathy is associated with VP1 C terminus mutants. The Journal of general virology. 2012 Jan;93(Pt 1):175-83.

7. Gorelik L, Reid C, Testa M, et al. Progressive multifocal leukoencephalopathy (PML) development is associated with mutations in JC virus capsid protein VP1 that change its receptor specificity. The Journal of infectious diseases. 2011 Jul $1 ; 204(1): 103-14$ 
8. Tan IL, McArthur JC, Clifford DB, Major EO, Nath A. Immune reconstitution inflammatory syndrome in natalizumab-associated PML. Neurology. 2011 Sep 13;77(11):1061-7.

9. Dahlhaus S, Hoepner R, Chan A, et al. Disease course and outcome of 15 monocentrically treated natalizumab-associated progressive multifocal leukoencephalopathy patients. Journal of neurology, neurosurgery, and psychiatry. 2013 Oct;84(10):1068-74.

10. Ryschkewitsch CF, Jensen PN, Monaco MC, Major EO. JC virus persistence following progressive multifocal leukoencephalopathy in multiple sclerosis patients treated with natalizumab. Annals of neurology. 2010 Sep;68(3):384-91.

11. Jelcic I, Jelcic I, Faigle W, Sospedra M, Martin R. Immunology of progressive multifocal leukoencephalopathy. Journal of neurovirology. 2015 Mar 5.

12. Du Pasquier RA, Kuroda MJ, Zheng Y, Jean-Jacques J, Letvin NL, Koralnik IJ. A prospective study demonstrates an association between JC virus-specific cytotoxic T lymphocytes and the early control of progressive multifocal leukoencephalopathy. Brain : a journal of neurology. 2004 Sep;127(Pt 9):1970-8.

13. Gheuens S, Bord E, Kesari S, et al. Role of CD4+ and CD8+ T-cell responses against $\mathrm{JC}$ virus in the outcome of patients with progressive multifocal leukoencephalopathy (PML) and PML with immune reconstitution inflammatory syndrome. Journal of virology. $2011 \mathrm{Jul} ; 85(14): 7256-63$.

14. Wuthrich C, Kesari S, Kim WK, et al. Characterization of lymphocytic infiltrates in progressive multifocal leukoencephalopathy: co-localization of CD8(+) T cells with JCV-infected glial cells. Journal of neurovirology. 2006 Apr;12(2):116-28. 
15. Martin-Blondel G, Bauer J, Cuvinciuc V, et al. In situ evidence of JC virus control by CD8+ T cells in PML-IRIS during HIV infection. Neurology. 2013 Sep 10;81(11):964-70.

16. Aly L, Yousef S, Schippling S, et al. Central role of JC virus-specific CD4+ lymphocytes in progressive multi-focal leucoencephalopathy-immune reconstitution inflammatory syndrome. Brain : a journal of neurology. 2011 Sep;134(Pt 9):2687-702.

17. Yousef S, Planas R, Chakroun $\mathrm{K}$, et al. TCR bias and HLA cross-restriction are strategies of human brain-infiltrating JC virus-specific CD4+ T cells during viral infection. Journal of immunology. 2012 Oct 1;189(7):3618-30.

18. Zonios DI, Falloon J, Bennett JE, et al. Idiopathic CD4+ Iymphocytopenia: natural history and prognostic factors. Blood. 2008 Jul 15;112(2):287-94.

19. Gillespie SM, Chang Y, Lemp G, et al. Progressive multifocal leukoencephalopathy in persons infected with human immunodeficiency virus, San Francisco, 1981-1989. Annals of neurology. 1991 Oct;30(4):597-604.

20. Jelcic I, Aly L, Binder TM, et al. T cell epitope mapping of JC polyoma virusencoded proteome reveals reduced $T$ cell responses in HLA-DRB1*04:01+ donors. Journal of virology. 2013 Mar;87(6):3393-408.

21. Sundqvist E, Buck D, Warnke C, et al. JC polyomavirus infection is strongly controlled by human leucocyte antigen class II variants. PLoS Pathog. 2014 Apr;10(4):e1004084

22. Schippling S, Kempf C, Buchele F, et al. JCV granule cell neuronopathy and GCN-IRIS under natalizumab treatment. Annals of neurology. 2013 Oct;74(4):622-6. 
23. Nakanishi A, Chapellier B, Maekawa N, et al. SV40 vectors carrying minimal sequence of viral origin with exchangeable capsids. Virology. 2008 Sep $15 ; 379(1): 110-7$

24. Zloza A, Schenkel JM, Tenorio AR, Martinson JA, Jeziorczak PM, Al-Harthi L. Potent HIV-specific responses are enriched in a unique subset of CD8+ T cells that coexpresses CD4 on its surface. Blood. 2009 Oct 29;114(18):3841-53.

25. Kitchen SG, Whitmire JK, Jones NR, et al. The CD4 molecule on CD8+ T lymphocytes directly enhances the immune response to viral and cellular antigens. Proceedings of the National Academy of Sciences of the United States of America. 2005 Mar 8;102(10):3794-9.

26. Nascimbeni M, Shin EC, Chiriboga L, Kleiner DE, Rehermann B. Peripheral CD4(+)CD8(+) T cells are differentiated effector memory cells with antiviral functions. Blood. 2004 Jul 15;104(2):478-86.

27. Kitchen SG, Korin YD, Roth MD, Landay A, Zack JA. Costimulation of naive CD8(+) lymphocytes induces CD4 expression and allows human immunodeficiency virus type 1 infection. Journal of virology. $1998 \mathrm{Nov} ; 72(11): 9054-60$.

28. Dang X, Koralnik IJ. Gone over to the dark side: Natalizumab-associated JC virus infection of neurons in cerebellar gray matter. Annals of neurology. 2013 Oct;74(4):503-5.

29. Agnihotri SP, Dang X, Carter JL, et al. JCV GCN in a natalizumab-treated MS patient is associated with mutations of the VP1 capsid gene. Neurology. 2014 Aug 19;83(8):727-32. 
30. Metz I, Radue EW, Oterino A, et al. Pathology of immune reconstitution inflammatory syndrome in multiple sclerosis with natalizumab-associated progressive multifocal leukoencephalopathy. Acta neuropathologica. 2012 Feb;123(2):235-45.

31. Dang L, Dang X, Koralnik IJ, Todd PK. JC Polyomavirus Granule Cell Neuronopathy in a Patient Treated With Rituximab. JAMA neurology. 2014 Apr;71(4):487-9.

32. Wuthrich C, Cheng YM, Joseph JT, et al. Frequent infection of cerebellar granule cell neurons by polyomavirus $\mathrm{JC}$ in progressive multifocal leukoencephalopathy. Journal of neuropathology and experimental neurology. 2009 Jan;68(1):15-25.

33. Kitchen SG, LaForge S, Patel VP, Kitchen CM, Miceli MC, Zack JA. Activation of CD8 T cells induces expression of CD4, which functions as a chemotactic receptor. Blood. 2002 Jan 1;99(1):207-12.

34. Kurschner C, Yuzaki M. Neuronal interleukin-16 (NIL-16): a dual function PDZ domain protein. The Journal of neuroscience : the official journal of the Society for Neuroscience. 1999 Sep 15;19(18):7770-80.

35. Liblau RS, Gonzalez-Dunia D, Wiendl H, Zipp F. Neurons as targets for T cells in the nervous system. Trends in neurosciences. 2013 Jun;36(6):315-24.

36. Sloan-Lancaster J, Allen PM. Altered peptide ligand-induced partial T cell activation: molecular mechanisms and role in $\mathrm{T}$ cell biology. Annual review of immunology. 1996;14:1-27.

37. Walton S, Mandaric S, Oxenius A. CD4 T cell responses in latent and chronic viral infections. Front Immunol. 2013;4:105. 
38. Sant AJ, McMichael A. Revealing the role of CD4(+) T cells in viral immunity. The Journal of experimental medicine. 2012 Jul 30;209(8):1391-5.

39. Jelcic I, Combaluzier B, Jelcic I, et al. Broadly neutralizing human monoclonal JC polyomavirus VP1-specific antibodies as candidate therapeutics for progressive multifocal leukoencephalopathy. Science translational medicine. 2015 Sep 23;7(306):306ra150. 


\section{FIGURE LEGENDS}

A

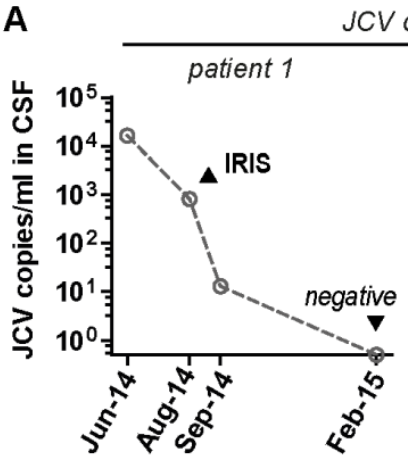

B

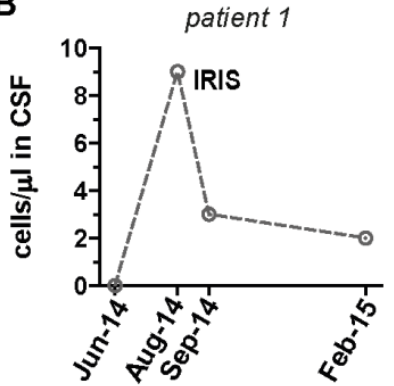

C
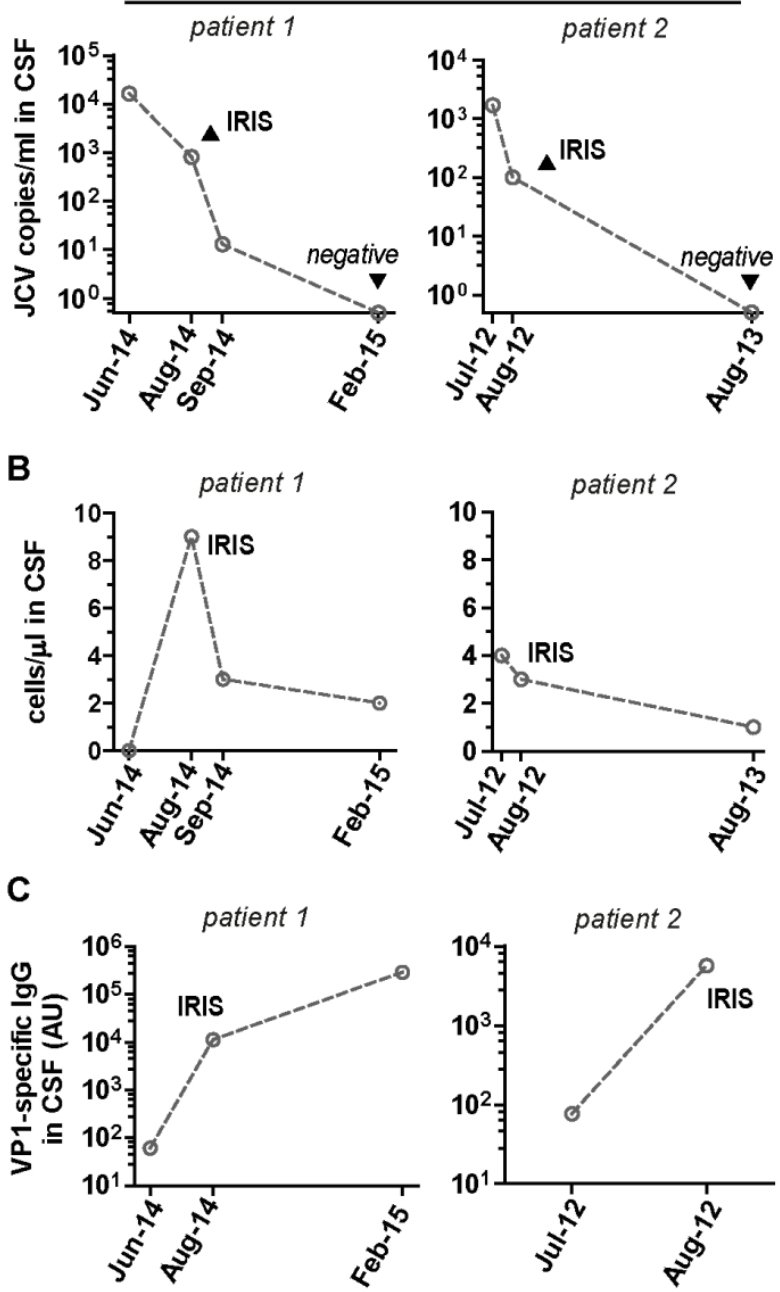

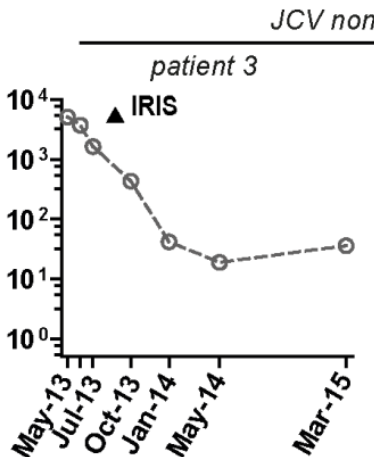

CV non-cleare
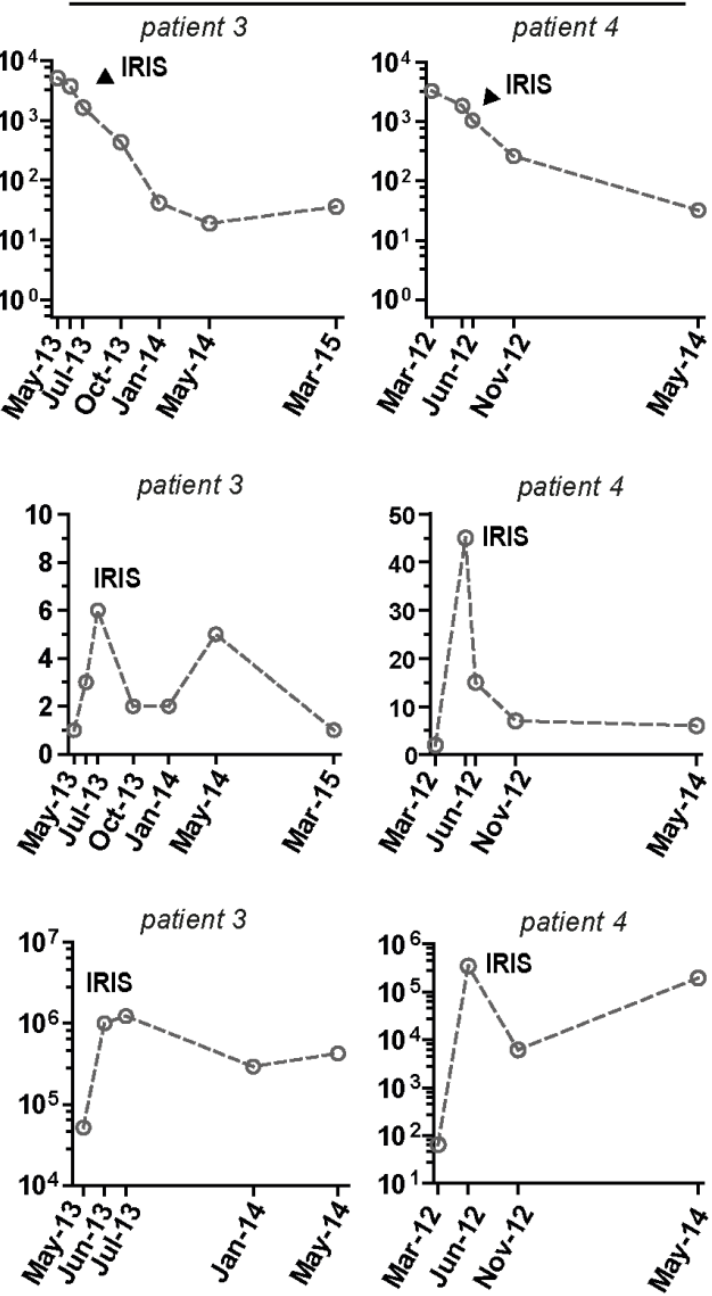

D CNS-infiltrating T cells (IRIS)

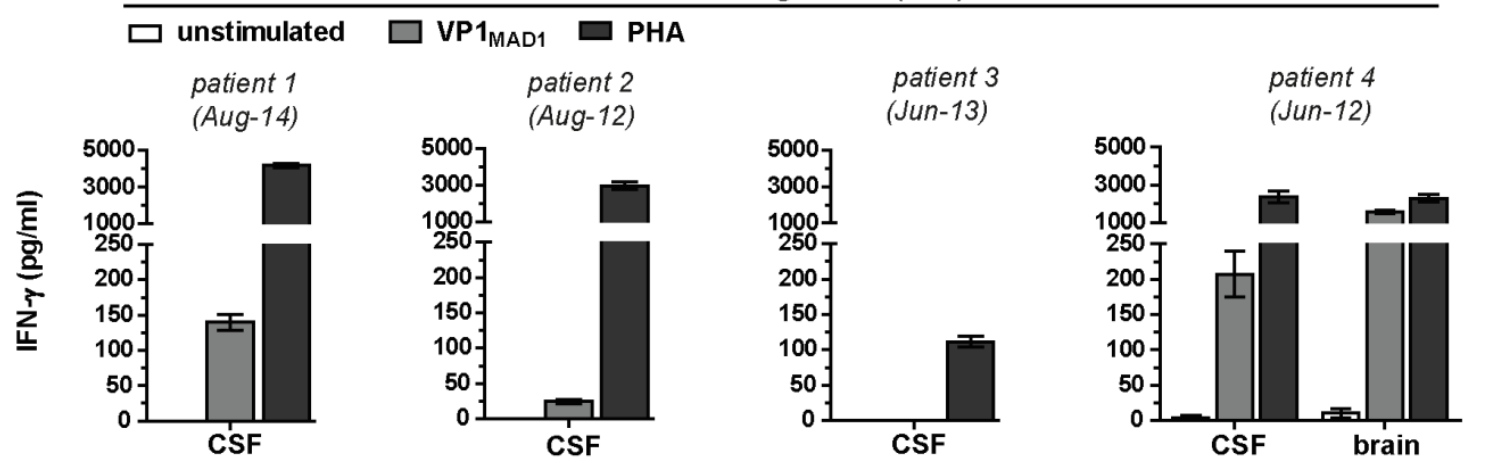

Figure 1. Delayed clearance of JCV in the CSF of natalizumab-associated JCV infection despite immune reconstitution. (A) JC viral load in CSF during course of JCV infection measured by quantitative PCR. (B) Cell numbers in CSF during course of JCV infection. (C) CSF antibody responses of natalizumab-associated PML 
patients to JCV VP1, expressed as AU. (D) PHA-expanded brain- or CSF-derived T cells from time point of IRIS were tested for reactivity to VP1 $1_{\text {MAD1 }}$ and PHA using autologous APCs. Results show the mean IFN- $\gamma$ secretion from four replicates +/SEM. 
A CSF-infiltrating T cells (IRIS)
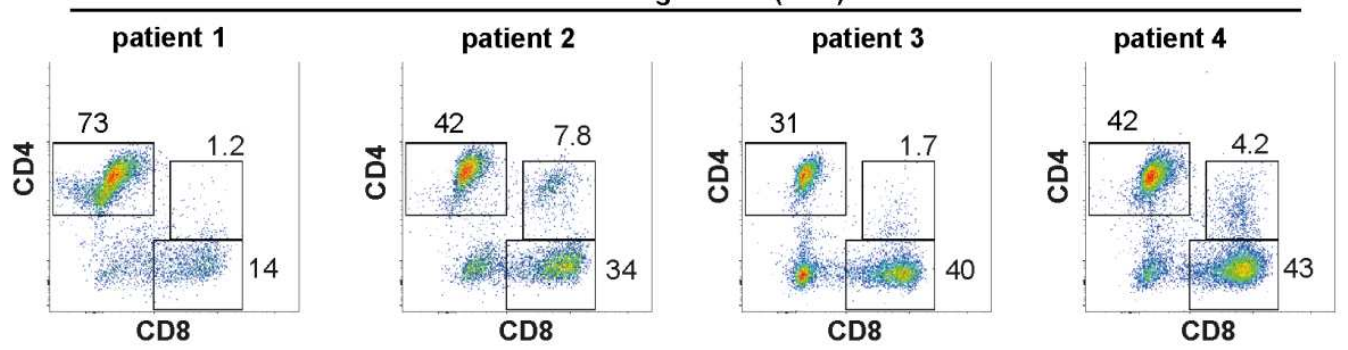

B
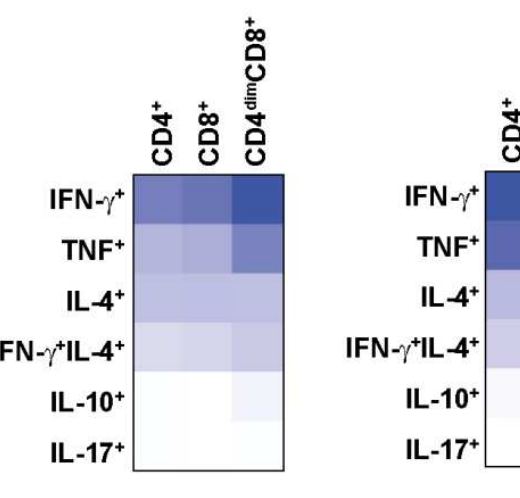

.

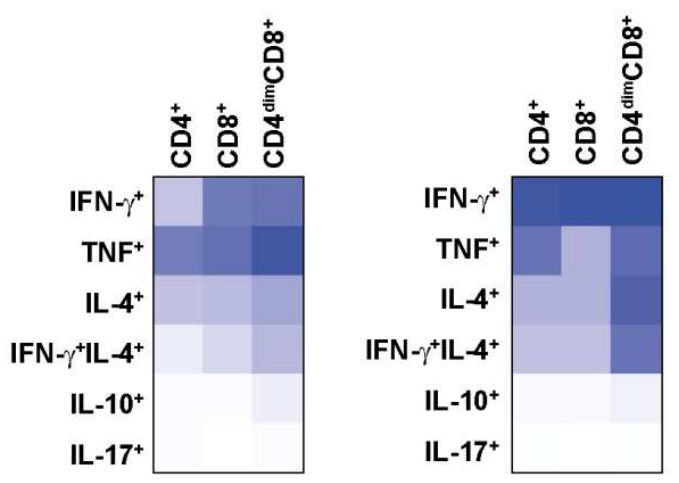

$\therefore \infty 8 \%$ ฟ

$\%$ frequency of positive cells

C
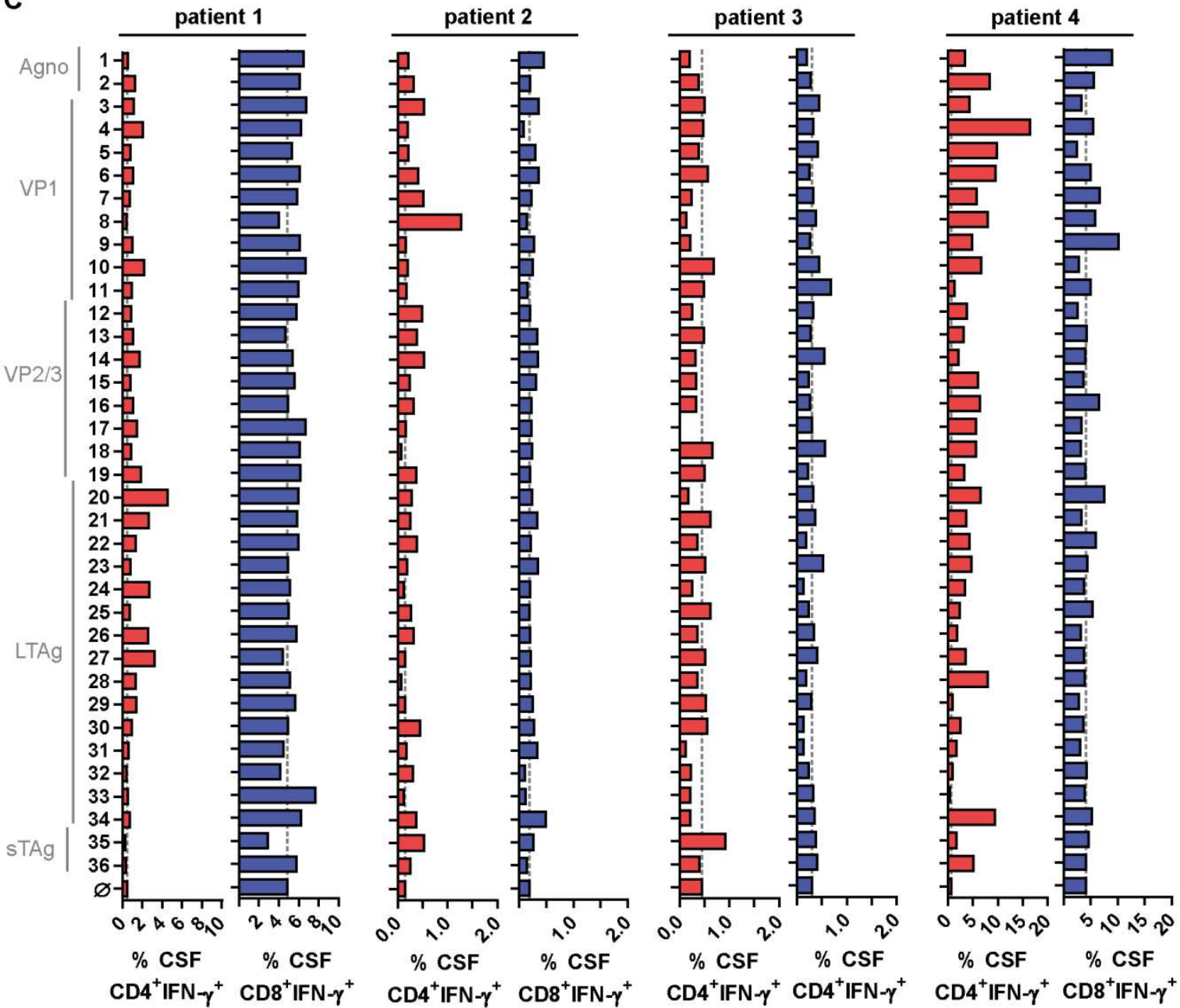
Figure 2. CSF-infiltrating $\mathrm{T}$ cells show a prominent $\mathrm{Th} / \mathrm{Tc1}$ phenotype with strong $\mathrm{CD4}^{+} \mathrm{T}$ cell responses to selective JCV antigens. (A) Composition of T cell subsets in the CSF infiltrate of all 4 patients at time point of IRIS. (B) Cytokine profile of brain $\mathrm{CD} 4^{+}, \mathrm{CD} 8^{+}$and $\mathrm{CD} 4^{\mathrm{dim}} \mathrm{CD} 8^{+} \mathrm{T}$ cells upon stimulation with PMA/lonomycin depicted as heat map. The percentage of positive cells is illustrated with a color gradient. (C) ICS of CSF-infiltrating T cells of all 4 patients. The graphs indicate the percentage of IFN- $\gamma^{+}$cells in the $\mathrm{CD} 4^{+}$(red) and $\mathrm{CD} 8^{+}$(blue) T cell compartment after restimulation with JCV peptide pools. The grey dotted line indicates the frequency of IFN- $\gamma^{+}$cells under unstimulated conditions, depicted as $\varnothing$. Prior gating included singlets, live and $\mathrm{CD}^{+}$cells. 
A

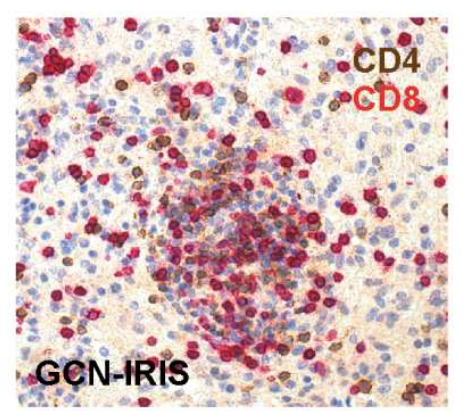

B

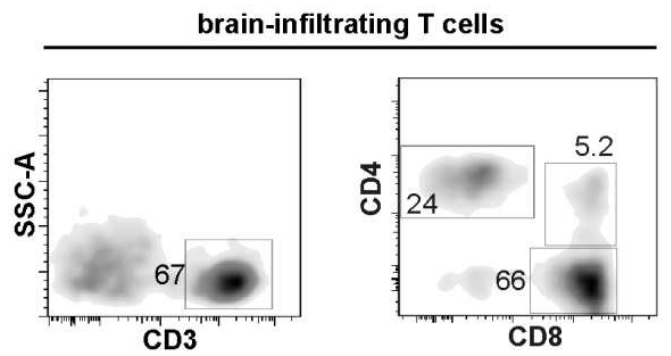

C

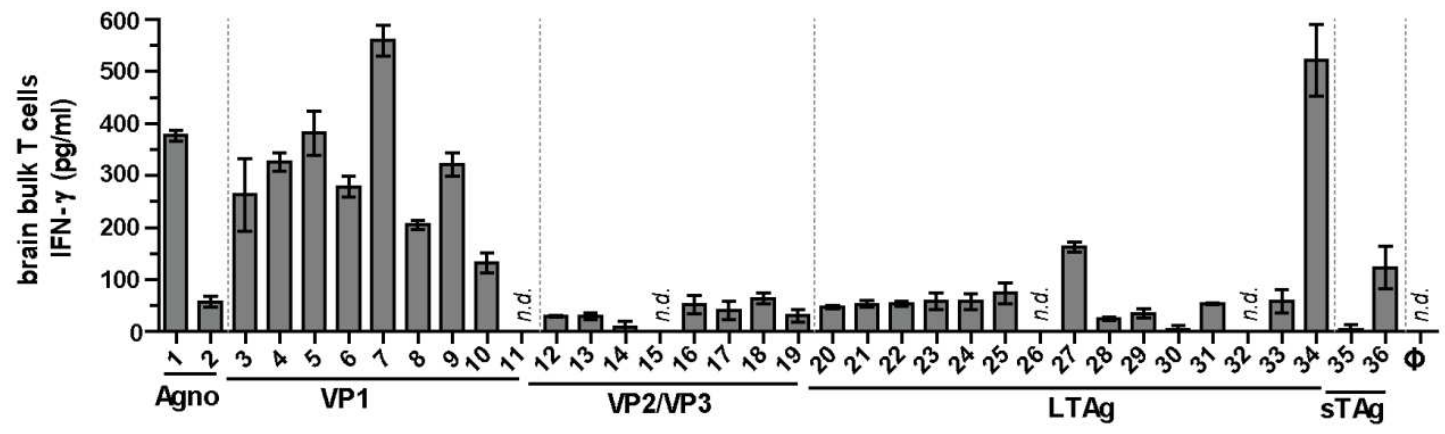

D
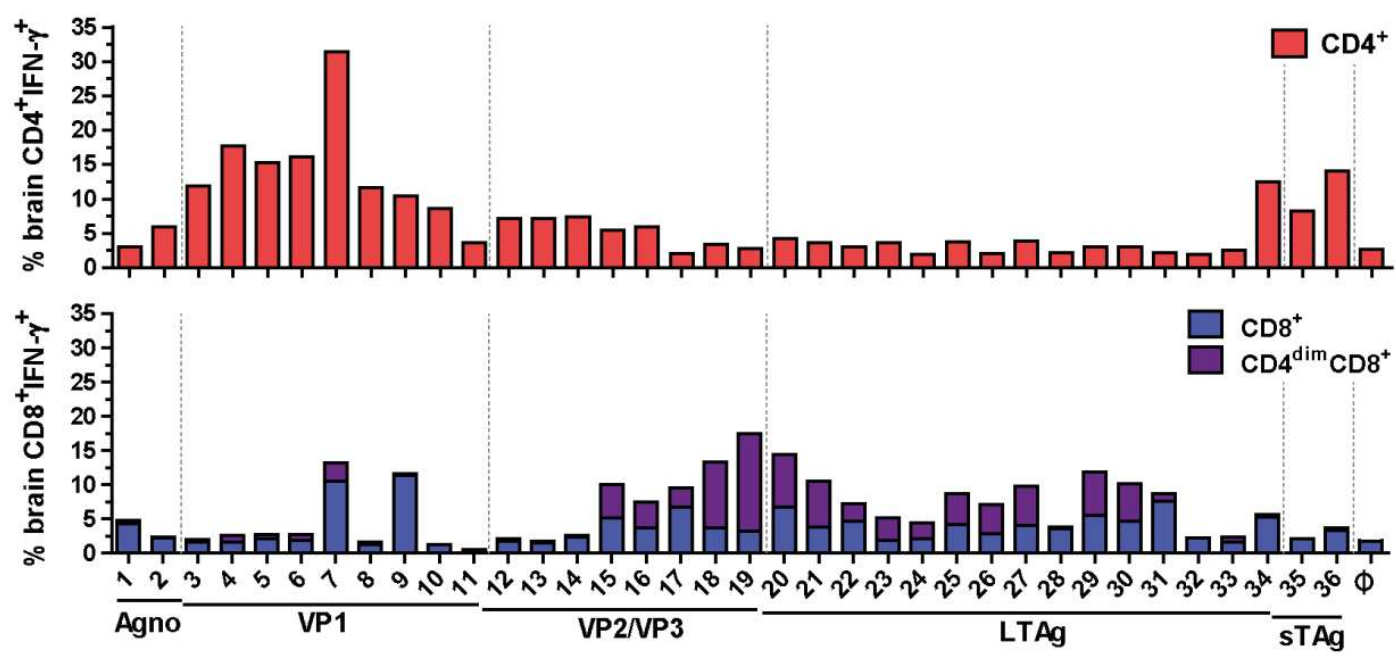

Figure 3. Epitope mapping of brain-infiltrating $\mathbf{T}$ cells reveals differential antigen specificity during neuronal JCV infection. (A) Infiltration of CD4 ${ }^{+}$(brown) and $\mathrm{CD}^{+}$(red) $\mathrm{T}$ cells in the cerebellum of patient 4 , who developed GCN. (B) Composition of $\mathrm{T}$ cell subsets in the brain infiltrate of patient 4 at time point of GCNIRIS. (C) IFN- $\gamma$ response of brain-derived T cells from the GCN-IRIS patient against 36 peptide pools spanning all open reading frames of JCV. Results show the mean of IFN- $\gamma$ secretion from four replicates +/- SEM. Values below standard range are indicated as not detectable (n.d.) and unstimulated conditions by $\varnothing$. (E) (D) ICS of 
brain-infiltrating T cells. The graphs indicate the percentage of IFN- $\gamma^{+}$cells in the brain $\mathrm{CD}^{+}$(red), $\mathrm{CD}^{+}$(blue) and activated $\mathrm{CD}^{+}$(corresponds to $\mathrm{CD} 4^{\mathrm{dim}} \mathrm{CD} 8^{+}$) (purple) T cell compartment after restimulation with JCV peptide pools. Prior gating included singlets, live and $\mathrm{CD}^{+}$cells. 
A
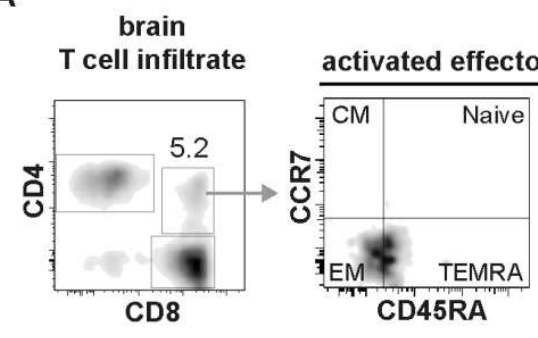

C
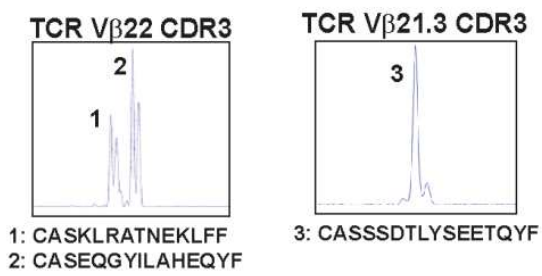

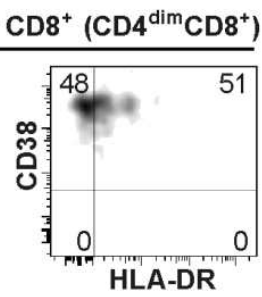

D

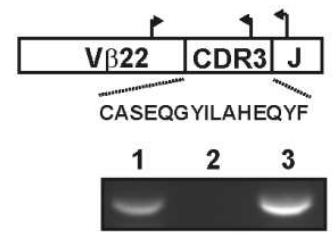

B

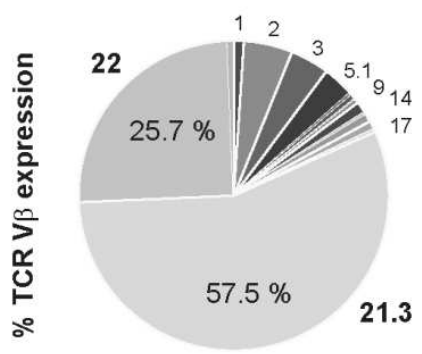

E

$\mathbf{F}$

*mutation sites
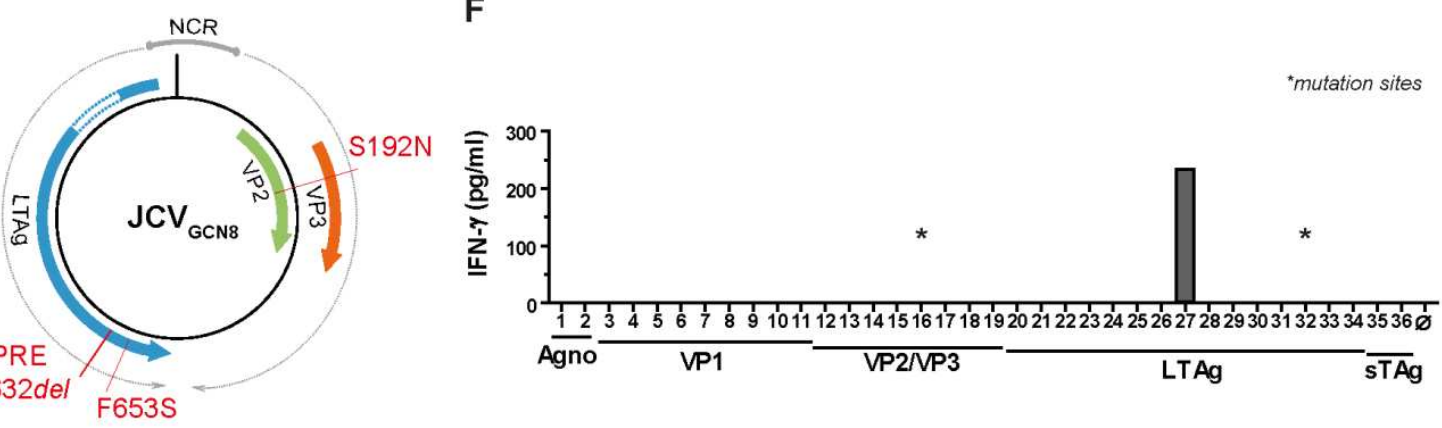

G

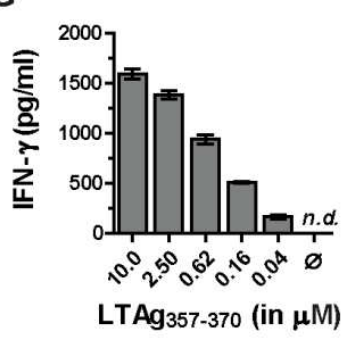

H

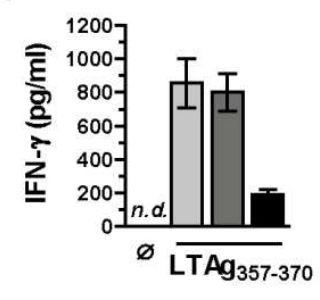

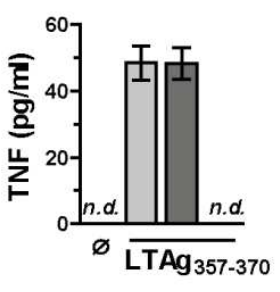

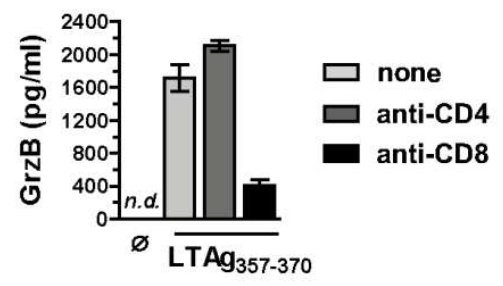

Figure 4. Activated $\mathrm{CDB}^{+} \mathrm{T}$ cells are enriched, clonally expanded and exhibit Tc1 responses against conserved LTAg epitopes. (A) Phenotyping of activated $\mathrm{CD}^{+} \mathrm{T}$ cell subset in freshly isolated brain infiltrate during GCN-IRIS. (B) TCR V $\beta$ chain distribution among expanded brain-infiltrating activated $\mathrm{CD} 8^{+}\left(\mathrm{CD} 4^{\mathrm{dim}} \mathrm{CD} 8^{+}\right) \mathrm{T}$ cells using TCR V $\beta$-chain-specific antibodies in flow cytometry. (C) Analysis of sorted TCR V $\beta 21.3^{+}$or TCR V $\beta 22^{+} \mathrm{CD} 4^{\text {dim }} \mathrm{CD}^{+} \mathrm{T}$ cells for clonal expansion by CDR3 spectratyping and sequencing. The respective CDR3 sequence is shown under the graph. (D) Fragments from PCRs specific for the CDR3 region, $\mathrm{V} \beta$ - and J-chain of 
the most prominent TCR sequences from brain $\mathrm{CD} 44^{\mathrm{dim}} \mathrm{CD} 8^{+} \mathrm{T}$ cells using CDNA of bulk $\mathrm{T}$ cells, enriched single $\mathrm{CD} 4^{+}$or $\mathrm{CD}^{+} \mathrm{T}$ cells from the brain as input. $(\mathrm{E})$ Scheme shows the location of amino acid mutations or deletions (del) in LTAg and VP2/VP3 of the identified cerebellar $\mathrm{JCV}_{\mathrm{GCN} 8}$ variant in comparison to $\mathrm{JCV}_{\mathrm{MAD1}}$. (F-G)

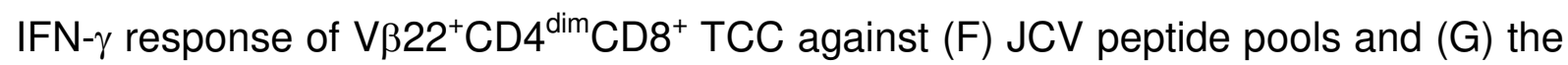
single peptide $\mathrm{LTAg}_{357-370}$ in a dose-dependent manner. $(\mathrm{H})$ Secretion of cytokines by $\mathrm{V} \beta 22^{+} \mathrm{CD} 4^{\mathrm{dim}} \mathrm{CD}^{+} \mathrm{TCC}$ in response to single peptide $\operatorname{LTAg}_{357-370}(0.1 \mu \mathrm{M})$ using ELISA. The TCC was incubated prior to stimulation with either a blocking antibody for CD4 or CD8. 
A

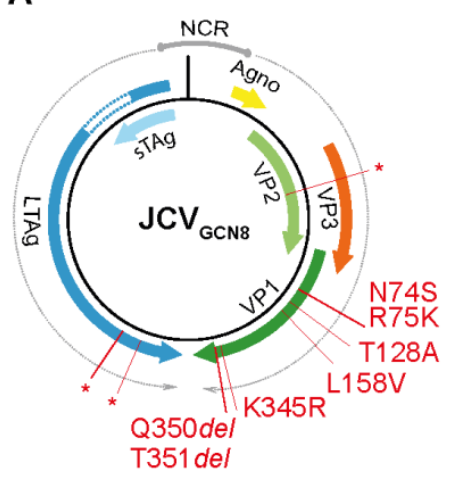

E

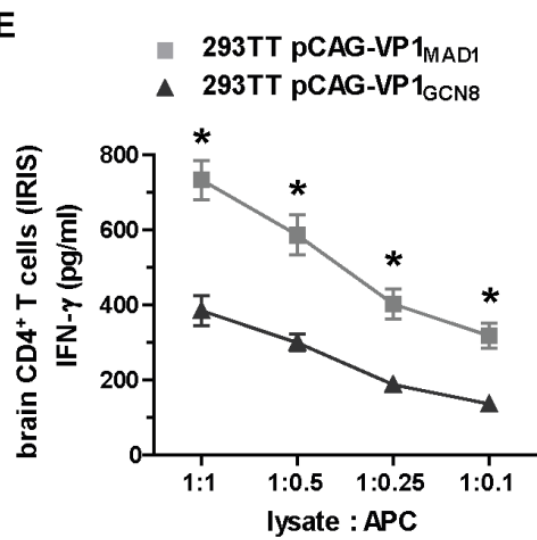

H

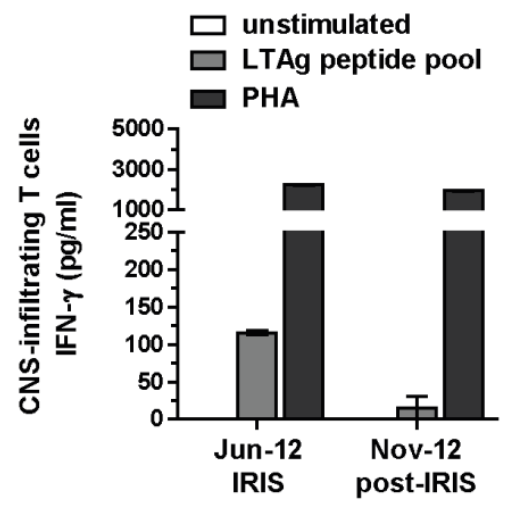

B

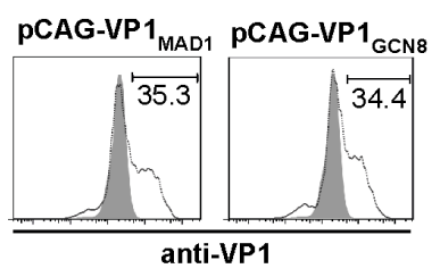

C

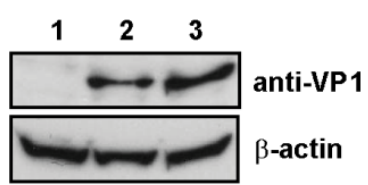

$\mathbf{F}$
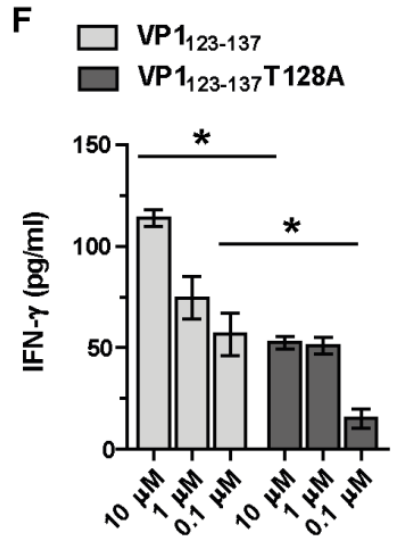

I

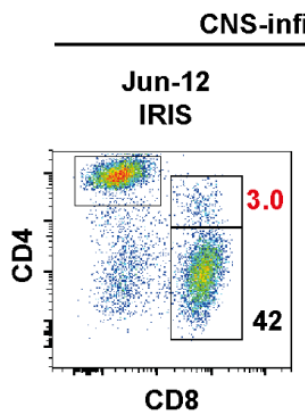

D

- 293TT untransfected

- 293TT pCAG-VP1 $1_{\text {MAD1 }}$

$\triangle$ 293TT PCAG-VP1 1 GCN8

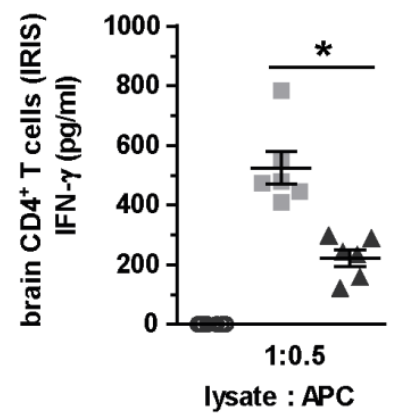

G

$\square$ peptide pool JCV MAD1 333-354 peptide pool JCV $\mathrm{GCN8}_{331-352}$

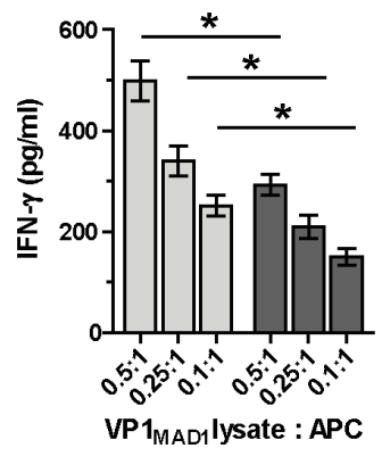

Figure 5. Mutations of $\mathrm{JCV}_{\mathrm{GCN} 8}$ VP1 modulate the $\mathrm{JCV}$-specific $\mathrm{CD}^{+} \mathrm{T}$ cell response and result in a decline of LTAg-specific $\mathrm{CD}^{+}{ }^{+} \mathbf{T}$ cells. (A) Scheme shows the location of amino acid mutations and deletions (del) in VP1 of the identified cerebellar $\mathrm{JCV}_{\mathrm{GCN} 8}$ variant in comparison to $\mathrm{JCV}_{\mathrm{MAD} 1}$. (B) Intracellular staining and (C) immunoblotting were used to control VP1 expression in untransfected (B, grey; C, 1), VP1 MAD1- $\left(\mathrm{B}\right.$, black; C, 2) or VP1 $1_{\mathrm{GCN} 8}$-transfected 293TT cells (B, black; $C, 3)$. ( $\mathrm{D}$ and $\mathrm{E})$ IFN- $\gamma$ response of PHA-expanded bulk brain $\mathrm{CD}^{+}{ }^{\mathrm{T}}$ 
cells after co-culture with APCs preincubated with lysates of untransfected, VP1 $1_{\mathrm{MAD} 1^{-}}$ or VP1 $1_{\mathrm{GCN} 8}$-transfected $293 \mathrm{TT}$ cells. The ratio indicates the amount of cells used for lysis in relation to the amount of APCs. The dots represent replicates of tested wells (D) or the mean $+/$ - SEM of six replicates (E). (F) IFN- $\gamma$ response of brain $\mathrm{CD}^{+} \mathrm{T}$ cells to $\mathrm{VP}_{123-137}\left(\mathrm{JCV}_{\mathrm{MAD} 1}\right)$ and $\mathrm{VP} 1_{123-137} \mathrm{~T} 128 \mathrm{~A}\left(\mathrm{JCV}_{\mathrm{GCN} 8}\right)$ peptides $(10 \mu \mathrm{M})$ in a dose-dependent manner (mean of triplicates +/- SEM). (G) Competition assay using VP1 $1_{\text {MAD1-transfected }}$ 293TT cell lysates at different ratios and peptide pools covering the C-terminal end of $\mathrm{VP} 1_{\mathrm{MAD} 1}$ or $\mathrm{VP} 1_{\mathrm{GCN}}$. IFN- $\gamma$ secretion is shown as mean of eight replicates $(+/-$ SEM). Asterisks indicate significant differences $(p$ value of $<0.05$ ) using a paired t-test. $(\mathrm{H})$ CSF-infiltrating T cell responses to LTAg, using a peptide pool covering the whole open reading frame of LTAg, as well as to PHA. (I) Distribution of $\mathrm{CD}^{+} \mathrm{T}$ cell subsets in expanded $\mathrm{T}$ cells from the CSF at onset of GCN-IRIS and after IRIS. 


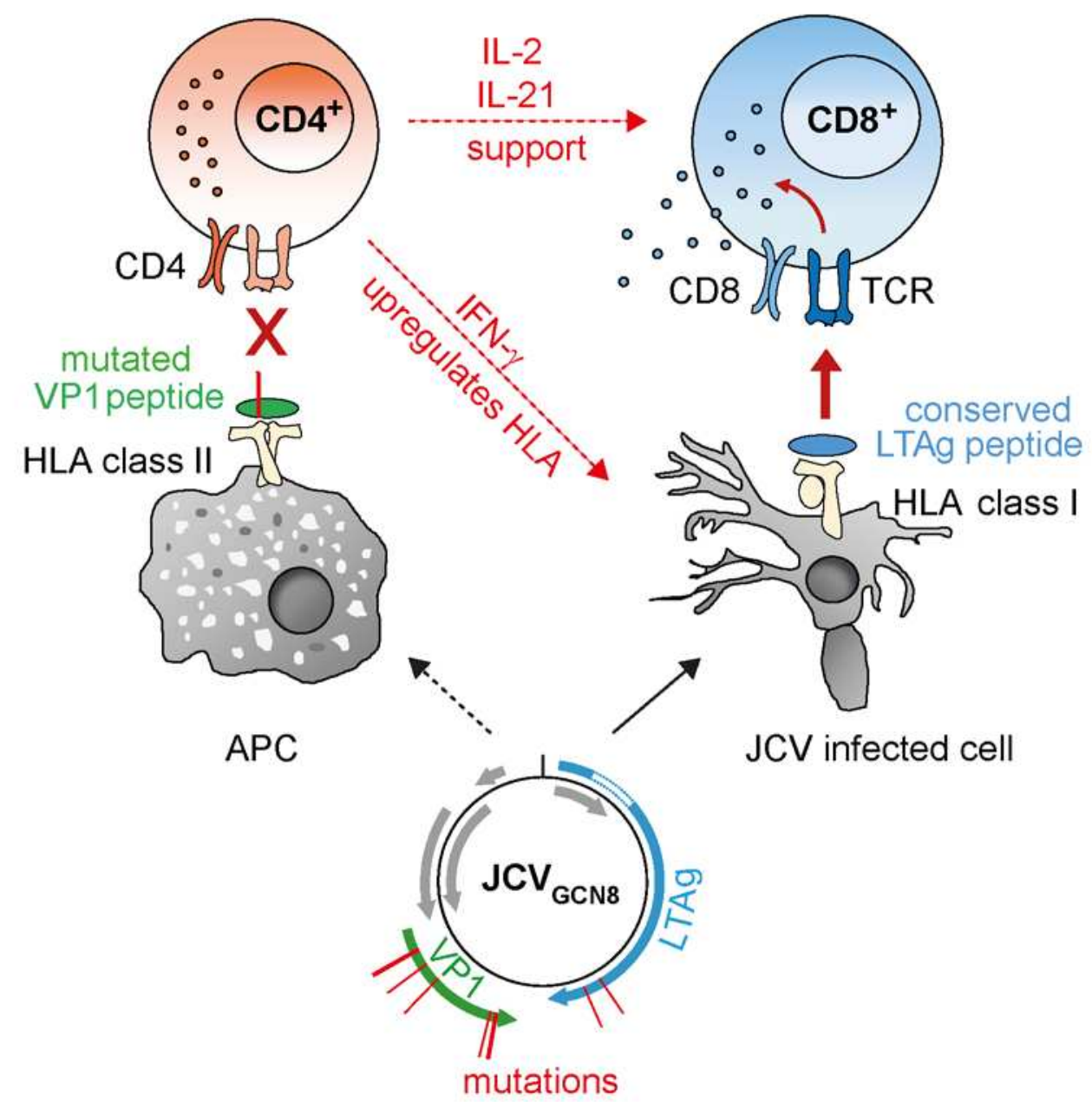

Figure 6. Overview of the role of $\mathrm{CD}^{+}$and $\mathrm{CD}^{+} \mathrm{T}$ cells in the clearance of $\mathrm{JCV}$ infection from the CNS. Mutations in the VP1 protein may generate altered peptides that escape efficient $\mathrm{CD}^{+} \mathrm{T}$ cell recognition resulting in inefficient Th1 effector functions. The latter affects cytokines like IFN- $\gamma$ that induce upregulation of MHC molecules on the target cells as well as supportive cytokines like IL-2 and IL-21 which are known to maintain proliferation and survival of $\mathrm{CD} 8^{+} \mathrm{T}$ cells. Reduction of these cytokines might cause impaired support for $\mathrm{JCV}$-specific $\mathrm{CD} 8^{+} \mathrm{T}$ cells that are crucial for eliminating JCV infection of the CNS. 